\title{
Meanders of the Polish Military Revolution - Standardization of Cavalry Units
}

\author{
K. Łopatecki, A. Boldyrew
}

For citation: Łopatecki K., Boldyrew A. Meanders of the Polish Military Revolution - Standardization of Cavalry Units. Vestnik of Saint Petersburg University. History, 2021, vol. 66, issue 2, pp. 464-489. https://doi.org/10.21638/11701/spbu02.2021.209

The objective of the article is to show the phenomenon of the internal standardization of the units of the Polish cavalry in the $16^{\text {th }}$ century. The references to this process, during which the diversisty of arms and equipment of soldiers was abandoned, are scarce in descriptive sources and are only reflected in normative acts. The only type of sources which enables to reconstruct the combat potential of units is inspection (rejestry popisowe). Consequently, the process of specialization of units and of formation of different types of cavalry was basically marginalized. In the Crown, as late as the 1530s, cavalry rotas were very diverse. They consisted of lancers, Polish winged hussars (later: hussars) and light cavalry combined in various proportions. This state of affairs is connected with three factors. Firstly, the units of Permanent Defense (obrona potoczna) in their structure referred to Mass Mobilization (pospolite ruszenie). Secondly, provisions of law were not used for standardizing the arms and armor; on the contrary, at least by the 1530s they stimulated the internal diversification. Thirdly, the Crown professional units were internally divided into towarzyszes and pocztowys, which prompted the diversification of armament inside a unit. The text shows the changes which occurred in the 1540s and 1550s, and brought about a situation in 1557, when the rate of standardization was as high as $82.93 \%$. The transformations were dynamic but were not top-down planned reforms, representing instead a bottom-up initiative of rotmistrzes.

Keywords: tactics of the $16^{\text {th }}$ century, types of Polish cavalry, military law, rejestry popisowe (inspection registers), military reforms, military revolution in the Crown.

Karol Łopatecki - Dr. Hab., Associate Professor, University of Bialystok, 20B, ul. Świerkowa, Białystok, 15-328, Poland; k.lopatecki@uwb.edu.pl

Карл Лопатеики - Dr. Наb., доц., Университет Белостока, Польша, 15-328, Белосток, ул. Швиеркова, 20B; k.lopatecki@uwb.edu.pl

Aleksander Boldyrew - Dr. Hab., Associate Professor, Uniwersytet Łódzki, 27a, ul. Kamińskiego, Łódź, 90-219, Poland; bow0@poczta.onet.pl

Александр Болдырев - Dr. Наb., доц., Лодзинский университет, Польша, 90-219, Лодзь, ул. Каминского, 27a; bow0@poczta.onet.pl

The article was written as part of the research project of the National Centre for Science SONATA, no. 2016/23/D/HS3/03210 titled "The military revolution as a modernization factor in the public finance and state organization of the Polish-Lithuanian state in the comparative perspective".

Статья написана в рамках исследовательского проекта Национального научного центра COHАТА № 2016/23/D/HS3/03210 «Военная революция как фактор модернизации государственных финансов и государственного устройства Польско-Литовского государства в сравнительной перспективе».

(C) St. Petersburg State University, 2021 


\section{К. Лопатецки, А. Болдьрев}

Для цитирования: Łopatecki K., Boldyrew A. Meanders of the Polish Military Revolution - Standardization of Cavalry Units // Вестник Санкт-Петербургского университета. История. 2021. Т. 66. Вып. 2. С. 464-489. https://doi.org/10.21638/11701/spbu02.2021.209

Цель статьи - показать феномен внутренней унификации отрядов польской конницы в XVI в. С этой целью мы вводим так называемый «коэффициент унификации» (“Standardization Rate” - SR), который обозначает процент солдат, соответствующих преобладающему типу конницы в данном отряде. Процесс стандартизации, в ходе которого было отброшено разнообразие в вооружении, неуловим в повествовательных источниках, лишь частично упомянут в нормативных актах, в то время как в иконографии представлен его идеализированный образ. Единственным типом источников (статистического характера), позволяющим воспроизвести реальный боевой потенциал подразделений, являются реестры («пописы») войск. В Польской Короне вплоть до 1530-х гг. роты конницы были очень разнообразны. Они состояли из смешанных в разных пропорциях копейников, гусар и легкой конницы. Такое положение дел было связано с тремя факторами. Во-первых, отряды, выполнявшие функции пограничных войск («обороны поточной»), относились по своей структуре к «посполитому рушению» (шляхетскому ополчению). Следовательно, вооружены они были довольно хаотично, о чем свидетельствует оснащение литовского «посполитого рушения» 1520 -х гг. (24 различных комплекта вооружения, почти полное отсутствие стрелкового оружия). Во-вторых, до 1530-х гг. нормы права не стимулировали изменения в этом отношении. В-третьих, отряды коронных войск были разнородными как в социальном, так и в материальном плане: они состояли из дворян, мещан, крестьян. Отмеченные в 1540-х и 1550-х гг. преобразования привели к росту «коэффициента унификации» (SR) до уровня 82,93\% в 1557 г. Отряды конницы из смешанных превратились в единообразные, основанные на двух родах солдат (гусар и казаков). Эти преобразования носили динамичный характер, но были не результатом реформ сверху, а инициативы, исходящей от ротмистров снизу. Только с начала 1560-х гг. правовые нормы привели к завершению всего процесса.

Ключевые слова: тактика XVI в., виды польской кавалерии, военное право, rejestry popisowe (ревизионные журналы), военные реформы, военная революция в Короне.

Permanent professional units emerged in the Crown in 1492, when they were called to protect the south-eastern borders (the so-called obrona potoczna or Permanent Defense) ${ }^{1}$. It was one of the forms of preventing the Tatar threat. The peoples being in various political structures (among which the Crimean Khanate was of the greatest importance), from 1468 onwards raided the Crown lands almost every year in search of prisoners, subsequently sold as slaves. Historiography connects the development of the old-Polish military with the quarter reform (reforma kwarciana) carried out in the period between 1564 and 1569. In those days a special treasury was established, comprising 1/5 of the revenue from royal domains, from which the quarter troops (wojsko kwarciane) were re-

${ }^{1}$ Kolankowski L. Roty koronne na Rusi i Podolu 1492-1572 r. // Ziemia Czerwieńska. 1935. T. 1, nr. 2. S. 141-142; Niemczyk K. Wojskowa emanacja władzy królewskiej w osobie hetmana na przełomie XV i XVI w. // Władza a społeczeństwo. Katowice, 2016. P. 154-155. 
munerated ${ }^{2}$. As regards the rules of funding, the reform was enormous. It was no longer the king who paid the soldiers from his own treasury, but the public treasury supervised by the Sejm (lower house of the Polish parliament). This guaranteed lower fluctuation of the army personnel and enabled to plan year-round protection of the borderline. However, the fiscal reorganization did not affect tactical changes. Researchers associate such reforms with the rule of Stephan Bathory (1576-1586), who was to reorganize the hussars granting them uniform weapons and equipment, which led to the standardization of armament, thereby raising its combat effectiveness ${ }^{3}$. Those reforms were expected to result in considerable increase in the combat qualities of the hussars, and consequently - in the boost of the military potential of the whole Commonwealth. Besides, it is conscientiously emphasized in scholarship that diversification in hussar units was taking place until the end of the $16^{\text {th }}$ century.

The aim of the article is to show the phenomenon of the internal standardization of cavalry units. We do not dismiss the importance of the remarkable reforms in the period of Stephan Bathory, but we want to underscore that key changes had occurred much earlier, already in the mid- $16^{\text {th }}$ century. The references to this process, during which the diversisty of arms and equipment of soldiers was abandoned, are scarce in descriptive sources and are only reflected in normative acts. The only type of sources which enables to reconstruct the combat potential of units is inspection registers. Using them as a statistical source makes it possible to draw far-reaching conclusions. Consequently, the process of specialization of units and formation of different types of cavalry was actually marginalized. The phenomenon was emphasized only by Marek Plewczyński, who recognized the years 1545-1549 as the time of the so-called Cossack reform, or the origins of the new light cavalry. This author also proposes a thesis that rearmament of the hussars involving adopting heavier protective armament (breastplates or cuirasses) and transforming them into heavy cavalry took place in the mid $-16^{\text {th }}$ century ${ }^{4}$. The problem was also pointed out by Henryk Kotarski; however, the issue was outside the main area of his studies ${ }^{5}$. We, however, are interested in the general phenomenon; we want to show the period and the scale of the transformations and primarily consider their causes.

In order to study the phenomenon, we introduce the "Standardization Rate" (hereinafter referred to as SR), which we understand as the percentage of soldiers serving in the

2 The quarter (kwarta) also included the fifth of duty tariffs and revenues from salt mines; from 1569 onwards it covered the lands incorporated into the Crown from the Grand Duchy of Lithuania. - Filipczak-Kocur A. Skarbowość Rzeczypospolitej 1587-1648. Projekty, ustawy, realizacje. Warszawa, 2006 (in particular P. 14-22); Pałucki W. Reformy skarbowe sejmu egzekucyjnego 1562/1563 r. // Studia historyczne. Księga Jubileuszowa z okazji 70 rocznicy urodzin prof. dra Stanisława Arnolda. Warszawa, 1965. S.301-313; Sucheni-Grabowska A. Walka o wymiar i przeznaczenie kwarty w końcu XVI w. i na początku XVII w. // Przegląd Historyczny. 1965. T. 56. S. 24-65 (see others articles by this author); Pałucki W. Drogi i bezdroża skarbowości polskiej XVI i pierwszej połowy XVII wieku. Wrocław, 1974; Plewczyński M. Żołnierz jazdy obrony potocznej za czasów Zygmunta Augusta. Studia nad zawodem wojskowym w XVI w. Warszawa, 1985 (in particular P. 52-53).

${ }^{3}$ For example: Spieralski Z., Wimmer J. Wstęp // Wypisy źródłowe do historii polskiej sztuki wojennej: in 13 vols. Vol. 1. Warszawa, 1961. S. 8-9; Cichowski J., Szulczyński A. Husaria. Warszawa, 1977. S. 15-19; Tomaszewski P. Husaria najlepsza jazda nowożytnej Europy // Saeculum Christianum. 2010. T. 17, nr. 1. S. 8-9.

${ }^{4}$ Plewczyński M. Napierśniki husarii obrony potocznej w połowie XVI w. // Studia z Dziejów Wojskowości. 2018. T.6. S. 161-178; Plewczyński M. Wojny i wojskowość polska w XVI wieku. T. 1-3. T. I: 15001548. Zabrze, 2011. S. 60-61; Głubisz B. Jazda kozacka w armii koronnej 1549-1696. Poznań, 2016. S. 7-8.

${ }^{5}$ Kotarski $H$. Wojsko polsko-litewskie podczas wojny inflanckiej 1576-1582. Dz. 1 // Studia i Materiały do Historii Wojskowości. 1970. T. 16, nr.2. S.92-93, 101-102. 
type of cavalry dominating in a particular unit. We can give SR not only for a single unit, but also for the whole army. The latter is calculated in the following way: the highest percentage of the particular type of cavalry in each unit is divided by the number of rotas, and the obtained result reflects the average percentage of the dominating formation. Certainly, all the criteria are conventional, but $90 \%$ SR, in our opinion, means the full standardization of the whole unit, whereas SR within the range $80-89.99 \%$ means an advanced process, which we refer to as partial standardization.

First, we want to present the main types of cavalry emerged in the first three quarters of the $16^{\text {th }}$ century. At the beginning of the century, the Crown cavalry was divided into three basic formations. The main strike force was made up by heavily armed lancers, who had their origins in the Middle Ages (see Fig. 1) ${ }^{6}$. That cavalry was of little use for the needs of the protection of the south-eastern borderlands invaded by the Tatars. The specificity of the enemy and the warfare required a light, fast soldier, flexible in action. Hence the popularity of the other type of cavalry, the hussars, modeled on the Hungarian formation ${ }^{7}$. They were riders armed in mail head and torso protection using asymmetric shields of Hungarian or Turkish origins and a light lance (see Fig. 2). The third category, the most diverse with changing armament, was the mounted shooters. As a rule, they were equipped with the so-called shooter armors and probably an open helmet, and also used various types of offensive weapons. At the beginning of the $16^{\text {th }}$ century, they used crossbows, which was not a good solution either, because of the character of the battlefield ${ }^{8}$. Thus, efforts were taken to rearm them with a long hand firearm, which were only partly successful.

After the transformations of the mid- $16^{\text {th }}$ century, the most precise description of different types of Polish riders was presented by Jan Andrzej Krasiński (1550-1612). He prepared it in 1573 for the needs of King-elect Henry de Valois. It was addressed to people unfamiliar with the reality of the Commonwealth. He distinguished three types of cavalry:

- heavily armed lancers with elements of plate armors, a lance and two-edged weapons: an estoc and a saber; some of them were also to possess short matchlocks and maces (budgeons);

- hussars with a chain mail and a chain mail hood, a light lance, a saber and a shield, some of them were to be equipped with bows or firearms;

${ }^{6}$ We can draw this conclusion from the amounts paid to particular soldiers (see: Archiwum Główne Akt Dawnych w Warszawie, Archiwum Skarbu Koronnego. Oddział 85. No. 13). It occurred even in the early thirties (see: Ibid. No. 19. P. 6, 10 and next). For more about the paid lancer heavy cavalry and its medieval origins see: Grabarczyk T. Jazda zaciężna Królestwa Polskiego w XV wieku. Łódź, 2015.

7 The first two units of this type were recruited in 1498 and 1503/1504. In 1498, the 105-men rota of Ferenc Raceni and Wacław Kamieniecki arrived in Poland (see: Grabarczyk T. Po racku, po husarsku, z przyprawą tatarską - początki przemian wojskowości polskiej u schyłku XV wieku // In tempore belli et pacis. Ludzie - Miejsca - Przedmioty. Warszawa, 2011. S. 119). The recruitment of the next unit was resolved during the Piotrków Sejm in 1503, and in 1504, a 50-horse unit was dispatched to Ruthenia (see: Plewczyński M. W służbie polskiego króla. Z zagadnień struktury narodowościowej Armii Koronnej w latach 1500-1574. Siedlce, 1995. S. 111-113).

${ }^{8}$ Kałużny J. T. U boku króla. Chorągiew nadworna królów Polski u schyłku XV wieku // Acta Universitatis Lodziensis. Folia Historica. 2019. T. 103. S. 68-69; Bołdyrew A. Piechota zaciężna w Polsce w pierwszej połowie XVI wieku. Warszawa, 2011. S.248-249. 


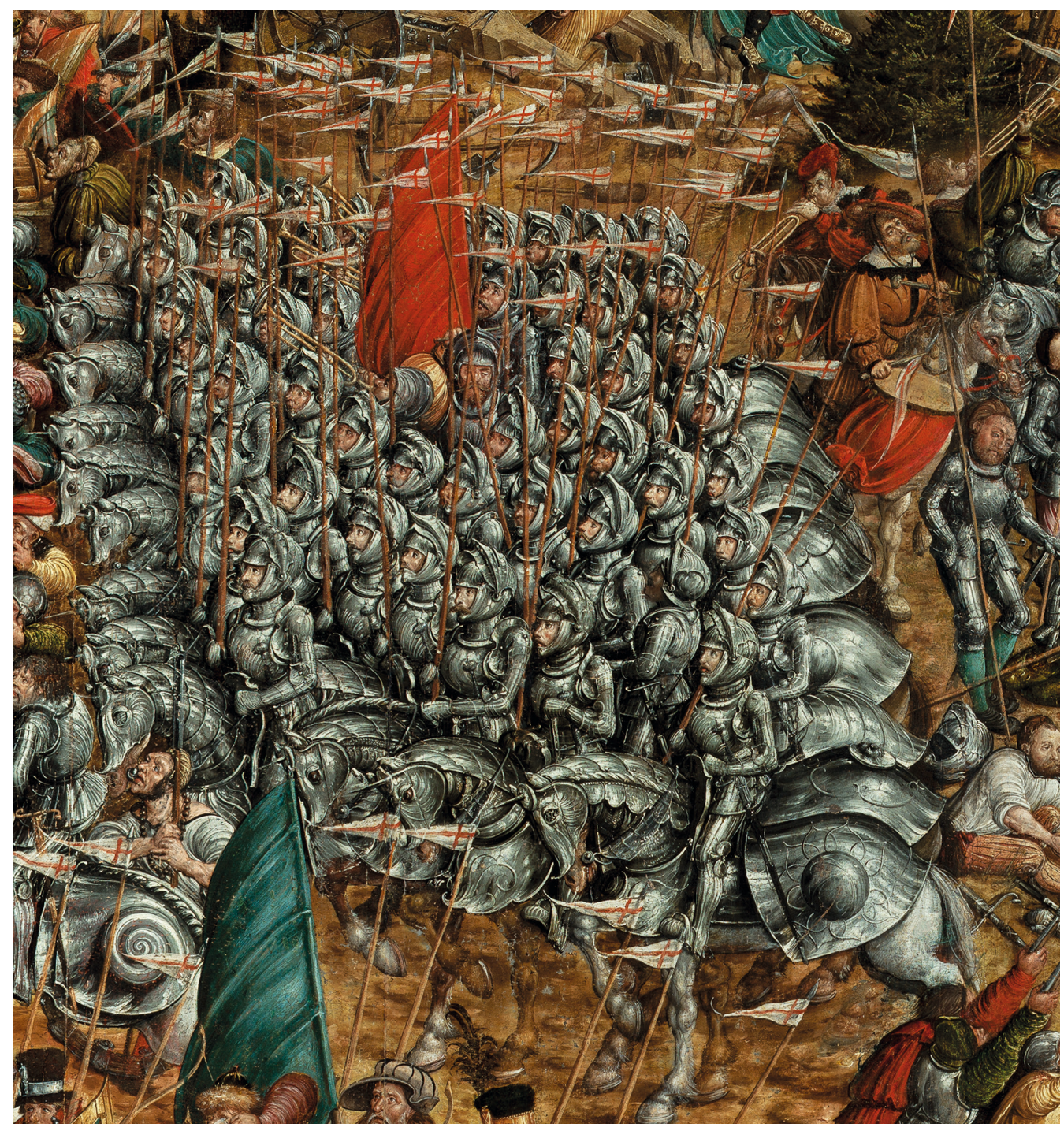

Fig. 1. A unit of lancers and hussars in the painting "The Battle of Orsha" [The National Museum in Warsaw, inv. No. MP 2475. URL: https://upload.wikimedia.org/wikipedia/commons/e/e0/Autor_ nieznany_\%28malarz_z_kręgu_Lukasa_Cranacha_Starszego\%29\%2C_Bitwa_pod_Orszą.jpg]

- lightly armed Cossacks, who used bows and quivers called "sahajdak", and saddles adapted for shooting from the horse"; moreover, sabers and spears with big spearheads (called rohatyna); the whole of this formation was modeled on the Tatar cavalry's armament ${ }^{10}$.

9 They were the so-called yarchaks, or Eastern-style saddles. They were represented in the xylograph in: Herberstein S. Rerum Moscoviticarum commentarii. Bazileae, 1571. S. 154-156. See: Sarnicki S. Księgi hetmańskie. Kraków, 2015. S. 211.

${ }^{10}$ Krasiński J. Polska czyli opisanie topograficzno-polityczne Polski w wieku XVI oraz materyały do panowania Henryka Walezyusza. Warszawa, 1852. S. 78-79, 158-159. 


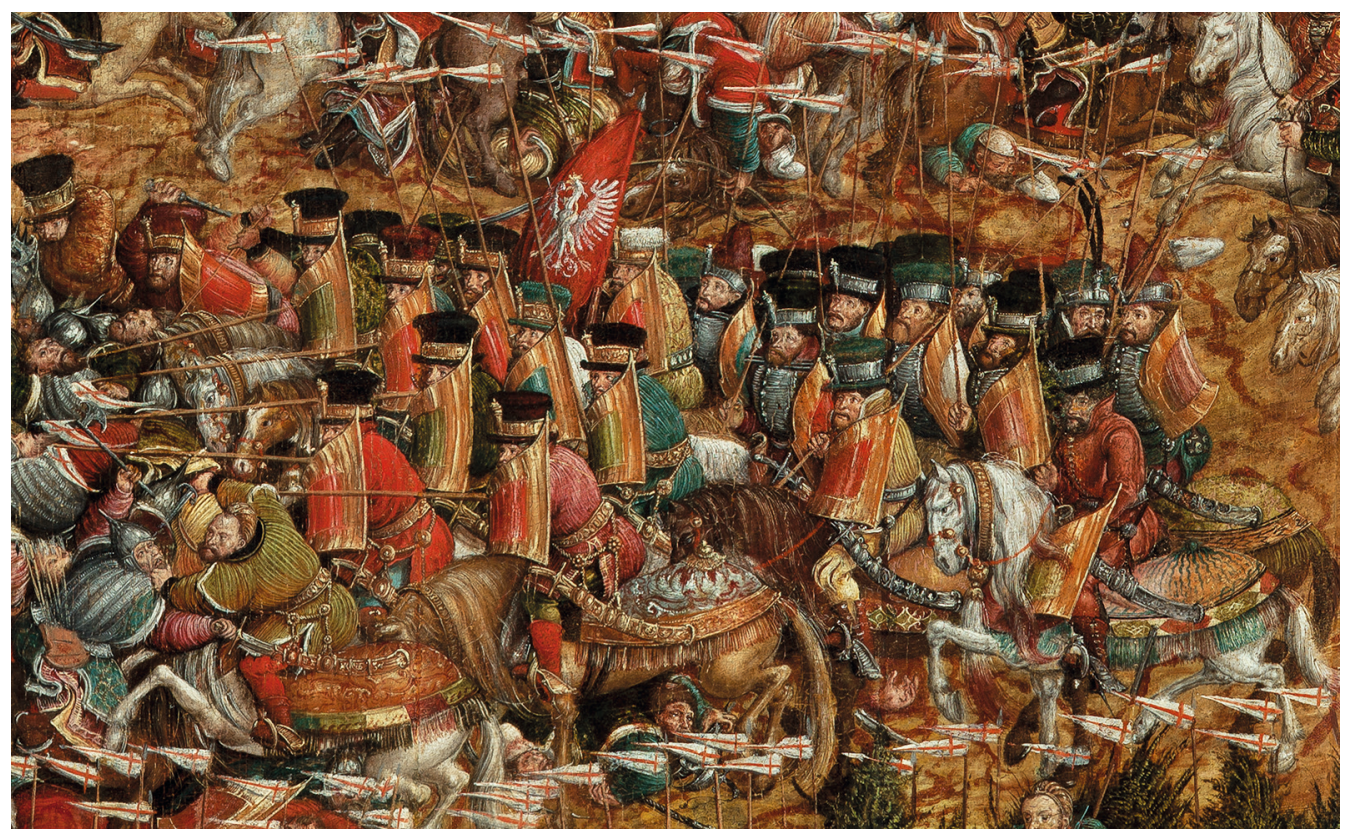

Fig. 2. A unit of hussars in the painting "The Battle of Orsha" [The National Museum in Warsaw, inv. No. MP 2475. URL: https://upload.wikimedia.org/wikipedia/commons/e/e0/Autor_ nieznany_\%28malarz_z_kręgu_Lukasa_Cranacha_Starszego\%29\%2C_Bitwa_pod_Orszą.jpg]

Thus, the units of mounted crossbowmen disappeared, and in their stead, there emerged Cossack riders. This may be connected with the process of verification of units' usefulness on the south-eastern borderline. Even within particular units there occurred a change in armament. The situation of the hussars is very characteristic: after the marginalization of the lancers, they began to transform into heavy cavalry through increasingly more frequent use of breastplates or cuirasses, which took place in the 1540 s and $1550 \mathrm{~s}^{11}$.

Discussing the types of cavalry, we are under an erroneous impression with regard to their composition. There is a conviction that they were more or less homogeneous, which seems confirmed by iconography representing standardized equipment of the troops. In particular, it concerns a monumental painting "The Battle of Orsha", where the lancers (Fig. 1) and the hussars (Fig. 2) have standardized equipment. The painting shows the battle of 1514 but was done in the 1530s, or maybe even in the $1540 \mathrm{~s}^{12}$. Narrative sources are of no help either; they usually ignore specific information on the armament. In reality, there were no such units (perhaps except parades ${ }^{13}$ ), which is well illustrated by the example of the Moldavian campaign of (summer-fall) 1531 (Fig. 3).

11 Plewczyński M. Napierśniki... S. 163-173.

12 Janicki M. A. Obraz Bitwa pod Orszą - geneza, datowanie, wzory graficzne, a obraz bitwy "na Kropiwnej" i inne przedstawienia batalistyczne w wileńskim pałacu Radziwiłłów // Bitwa pod Orszą. Warszawa, 2015. P. 176-177, 221.

13 Orzechowski S. Opisanie obrzędu ślubnego Zygmunta Augusta z Katarzyną Austriaczką // Zbiór pamiętników historycznych o dawnej Polszcze: w 6 t. T. V. Puławy, 1840. S. 325-345. 


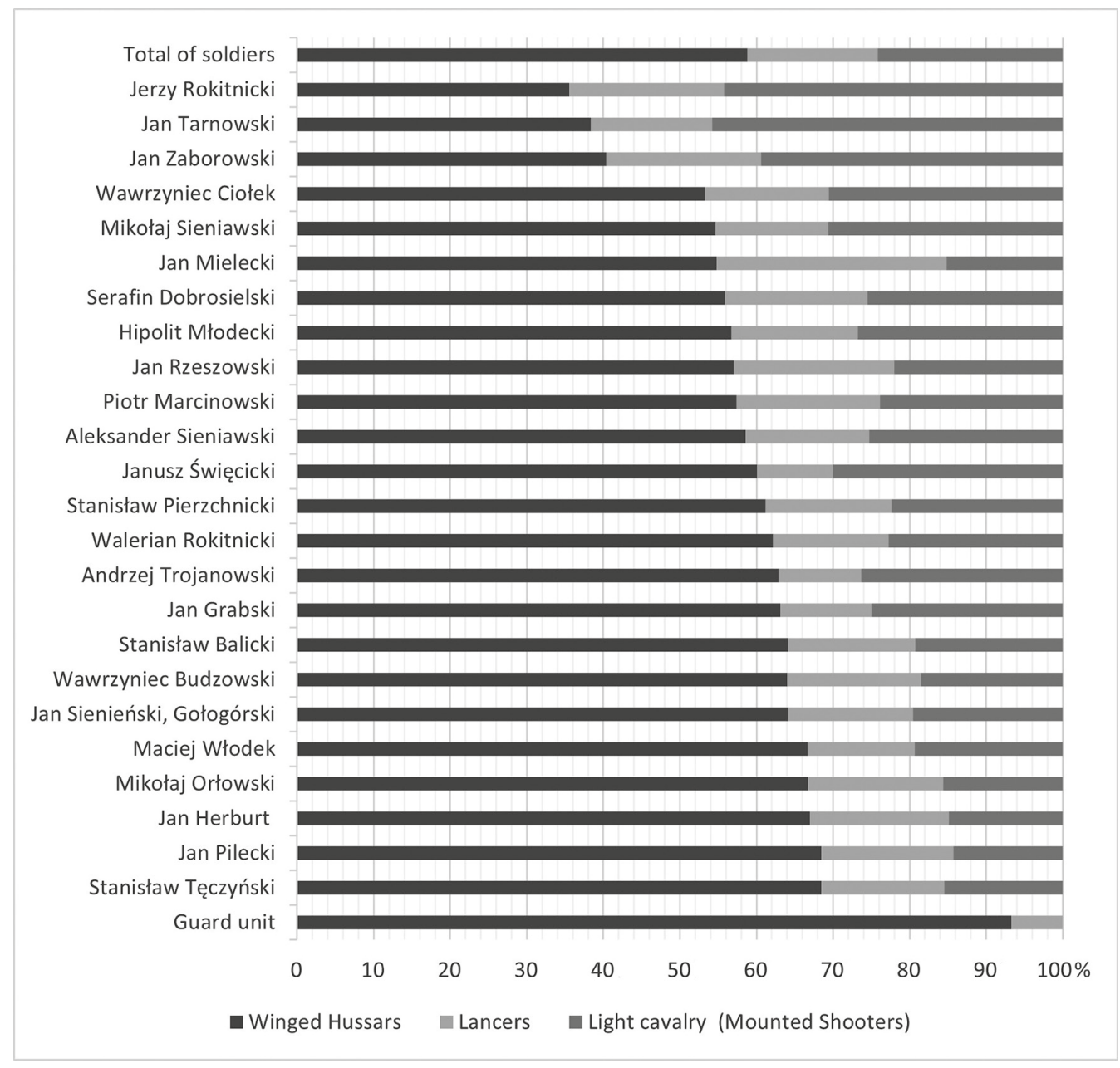

Fig. 3. The composition of cavalry rotas (names of rotmistrzes) in the Moldavian campaign of 1531, by a cavalry category. Prepared by the authors on the basis of: [Archiwum Główne Akt Dawnych (Warsaw), Archiwum Skarbu Koronnego. Oddział 85. No. 19. L.3-206; Spieralski Z. Kampania obertyńska 1531 roku. Warszawa, 1962. S.220-237]

On the basis of 4,422 soldiers serving in 1531 in 24 rotas, we can state that none of cavalry units was uniformly armed ${ }^{14}$. SR was merely $60.19 \%$. All rotas presented a mixture of heavy cavalry (lancers), medium (hussars) and light (shooters). Almost everywhere the hussars dominated (56.2\%), the number of whom fluctuated from $33.3 \%$ to $68.5 \%$. An-

${ }^{14}$ It is important, however, to explain that the identification of particular armament categories carried out by Spieralski is not entirely up-to-date now. For example, in the guard unit of Mikołaj Sieniawski two lancers were noted, but the analysis of source records does not confirm this interpretation. The two soldiers recognized as lancers did mount lancer horses but they did not have the armament typical of this category of soldiers (Archiwum Główne Akt Dawnych (Warsaw), Archiwum Skarbu Koronnego. Oddział 85. No. 19. L. 14). Thus, Spieralski identified the category on the basis of the type of the horse used. There are far more such examples, which enables to finally define the number of the lancers in particular rotas as even lower (this question requires further studies). 
other group was the shooters (27.5\%), who made up $15-45.8 \%$. The lowest number was comprised by the lancers (16.3\%), whose share was within the range $9.9-21 \%$. Zdzisław Spieralski clearly failed to include fencers, i.e., the riders equipped with edged weapon only, in his analysis of sources. In the 1540 s, there were as many as $16 \%$ of them ${ }^{15}$, so the armament structural mosaic in particular units was even more complicated.

The best SR, of $68 \%$, was noted in the rotas of Jan Pilecki and Stanisław Tęczyński. It is important to remember that the differences in the saturation of particular types of armament were small, and the general characteristics of a unit can be assessed by the number of particular soldiers. Hence, the elements of light cavalry dominated in the rotas of Jan Tarnowski, Jan Mielecki, Jerzy Rokitnicki and, probably, of Jan Zaborowski. Heavily armed rotas can be distinguished after summing up the hussars and the lancers; then we can recognize as such the units of Jan Pilecki, Jan Herbut, Stanisław Tęczyński and Mikołaj Orłowski.

The data are surprising and demonstrate the horrible state of the army organization. Each unit is made up by a medley of various types of armament. What did the primitive military structure, which existed even 40 years after the Permanent Defense had been formed in 1492, result from? We evaluate this phenomenon from three perspectives. First, it was a remnant of the medieval specificity, where the armament depended on the person whom it concerned. Second, it was a consequence of normative acts which promoted or failed to prevent internal diversity. Third, it was a result of the internally heterogeneous organization of paid units.

Creating mercenary cavalry at the end of the $16^{\text {th }}$ century did not change much in the composition of the units ${ }^{16}$. Recruitment was basically conducted among inhabitants of the Crown. Thus, the only difference between them and the mass mobilization (pospolite ruszenie) was that they were volunteers, probably better trained, healthier and physically stronger than average conscripts of mass mobilization ${ }^{17}$. The new type of troops did not introduce standards of uniformed or minimal equipment. Therefore, everyone took to the army what he possessed at home. Thus, the model of the mass mobilization was copied here.

The problem is that we actually do not know what that model was like. Precise inspection registers of paid soldiers kept on the territory of the Crown were connected with the necessity of paying the troops their wages and primarily compensation for damages in horses and armament. There were no such circumstances in the mass mobilization (pospolite ruszenie), and consequently the sources we need are missing. Fortunately, the armament was noted specifically in the Lithuanian mass mobilization ("służba ziemska"), in a unique and previously not examined register of $1524^{18}$. The next such detailed de-

15 Plewczyński M. Napierśniki... S. 162.

16 Of course, this assumption is general. The detailed analysis of the soldiers serving in the years 1500-1574 made by Marek Plewczyński enabled to evaluate that foreigners made up $21.7 \%$ (mostly Germans, $7 \%$, and Czechs and Moravians, $3.3 \%$, as well as Ruthenians $2.5 \%$ ). The aforementioned recruitments were mostly carried out for the needs of warfare against the Teutonic Knights, Moldavia, the Moscow Tsardom, and did not concern Permanent Defense. Plewczyński M. W służbie polskiego króla. S. 190-210.

17 Marek Plewczyński's calculations referring to the service of towarzyszes in Permanent Defense deserve attention (Plewczyński M. Żołnierz... S. 140). Even $90.2 \%$ of towarzyszes did their military service for up to 5 years, and over half of them spent in the army not more than a year! Thus, it was already a paid army but it is difficult to call it professional.

18 Popisy wojskowe pospolitego ruszenia Wielkiego Księstwa Litewskiego (1524-1566) / eds G. Lesmaitis, K. Łopatecki, B. Piasecka (tl.). Białystok, 2016. S. 1-19. 
scription was not made until a completely different period in the history of armament, in $1565^{19}$.

Three registers have survived from that period: of the nobility from the districts of Wasiliszki (Vasilishki), Ostryna and Żołudek; from Rudomino; and from Miedniki. 407 soldiers were described there altogether, and if 4 drabs (infantrymen) are subtracted from the total number, there are 403 riders (respectively, they were choragiews (rotas, units of mounted soldiers) of 189,109 and 105 men). The results of the analysis are amazing. Those soldiers had at their disposal as many as 24 different sets of armament and armor $^{20}$. This shows a wide diversity in armament ${ }^{21}$. However, to simplify this complex combination, we introduce a few main types of cavalry. It was a very difficult task since it is incongruous with our intuitive image of military units. The Memorial of Jan Ostrorog written circa 1477, is of certain assistance, which was pointed out by Tadeusz Grabarczyk $^{22}$.

1. Heavy cavalry (lancers), defined in the source as men equipped with weapons. The register also notes men in big units (poczets) of officials and affluent people. Probably those riders had lances, edged weapons and at least elements of plate $\operatorname{armor}^{23}$.

2. Medium cavalry, who had lances, edged weapons, and also armors, and some of them - shields. This category may also include men protected by armors but without polearms, as well as those who had lances but without armors. A key element of this category was armors and lances. That category was called by its contemporaries "półkopijnik" (semihastarius or demi-lancers) ${ }^{24}$.

3. Lithuanian hussars. In contrast to the classic Crown hussars, those soldiers were armed with spears with big heads (rohatyna), and not lances ${ }^{25}$. This category in-

19 Popisy wojskowe... S. 133-379.

20 Below we present different forms of armament; by default, if not marked otherwise, the soldier was equipped with a saber: zbrojno (armed) (93); rohatyna (spear with a big spearhead) (65); mail armor (66); shield and rohatyna (51); sword (26); plate armor (19); nothing (14); mail armor and rohatyna and shield (13); nmail armor and lance (10); mail armor as well as lance and shield (9); kord (cutlass) (8); shield (7); leather jacket (7); lance (4); sahajdak (bow and quiver) (3); mail armor and rohatyna (2); sword and shield (1); sword and rohatyna (1); sword and lance (1); falchion and rohatyna (1); mail armor and shield (1); lance and shield (1).

21 In the court Crown unit (chorągiew) of 1500 similar in terms of the number of soldiers, there were "merely" nine different types of armament per 324 riders (Kałużny J. T. U boku króla. S. 68-69).

22 Ostrorog J. Monumentum pro Reipublicae ordinatione // Pawiński A. Jana Ostroroga żywot i pismo o Naprawie Rzeczypospolitej. Studyum z literatury politycznej XV wieku. Warszawa, 1884. S. 160, 162; Grabarczyk T. Uzbrojenie w rocie konnej Aleksandra Sewera z 1498 roku // Archaeologia Historica. 2009. T. 34, nr. 1. S. 447.

23 Once it was added that Jakub Raklewicz was prepared "zbrojno" (armed), but with a comment that he possessed a shield and a lance (Popisy wojskowe... S. 16).

24 Ostrorog J. Monumentum... S. 160. - Under this term he understands lancers without the full armor, but just with a mail armor, a mail hood, a cuirass, a bevor and gauntlets.

25 The spear with a big spearhead (rohatyna) was originally a hunting weapon (bear spear). While hunting, it was equipped with a cross-bar made of animal horn or steel. Probably hence its name (rohatyna = spear with big spearhead with a hook or a horn). However, in the military use it was a regular spear, 2-2.5 meter-long, with a big spearhead. The hook or horn was not necessary during a combat from the saddle. At most, it could cause pulling the weapon off the soldier's hand. The rohatynas are, for example, mentioned in: Crescentyn P. Księgi o gospodarstwie y opatrzeniu rozmnożenia rozlicznych pożytkow każdemu stanowi potrzebne. Kraków, 1542. S. 634; Sarnicki S. Księgi hetmańskie. S. 304; Bielski M. Kronika polska. Sanok, 1856. S. 154, 447. 
cludes both soldiers equipped with shields and armors and those with one or neither of the elements.

4. Light cavalry, without any armor, and without any polearms but with edged weapons only. This category also includes soldiers with edged weapons and shields only. They were referred to by their contemporaries as fencers (gladiators) ${ }^{26}$.

5. Shooter cavalry, where the riders were armed with a bow case with a bow and a quiver with arrows (sahajdak) ${ }^{27}$.

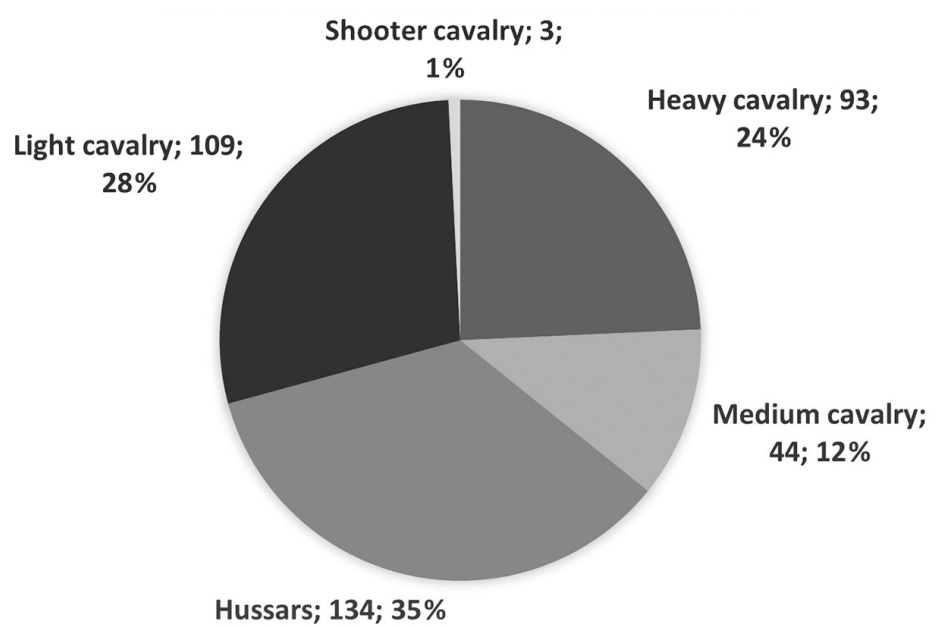

Fig. 4. Types of cavalry soldiers of the Lithuanian mass mobilization in 1524. Prepared by the authors on the basis of: [Popisy wojskowe... S. 1-19]

What is striking is the fact that the soldiers of land service almost never used bows; at least one item of firearms or a crossbow was not recorded. The lack of offensive weapons is an unusual situation, which meant that the main difference between the cavalry of land service and professional soldiers was high saturation of the latter with weapons used for long-distance combat ${ }^{28}$. The dominating type of troops were Lithuanian hussars, but they made up merely $35 \%$. There were still quite a number or lancers $(24 \%)$, while the worst armed light cavalry included as many as $28 \%$ of knights (see Fig. 4).

All conscripted soldiers possessed a type of edged weapon. The vast majority of weapons (circa 5\%) was represented by a saber, $12 \%$ - by swords, and the remaining $3 \%$ - by kords (cutlasses, falchions). Quite a number of pole arms was also noted; $61 \%$ of all warriors possessed them: mostly they were men armed with spears with big spearheads $(32 \%)$ and slightly less - with lances $(29 \%)$. The key difference between the nobles who organized poczty (a sub-unit) during mass mobilization was not the type of offensive

${ }^{26}$ Ostrorog J. Monumentum... S. 160, 162. - According to the author, they should have swords, shields and helmets.

27 About the characteristics of this weapon, see: Sarnicki S. Księgi hetmańskie. S. 223-224.

${ }^{28}$ For example, in Aleksander Sewer's cavalry rota of 1498, there were as many as 41 crossbows $(54.7 \%)$ and 4 items of powder arms (5.3\%) per 75 soldiers, whereas in the court choragiew (rota) of 1500 , as many as 189 crossbows, 10 bows, and 1 firearm (respectively: $58.3 \%, 3 \%$ and $0.3 \%$ ) per 324 riders. See: Grabarczyk T. Uzbrojenie... S. 445-453; Kałużny J. T. U boku króla. S. 59-72. 


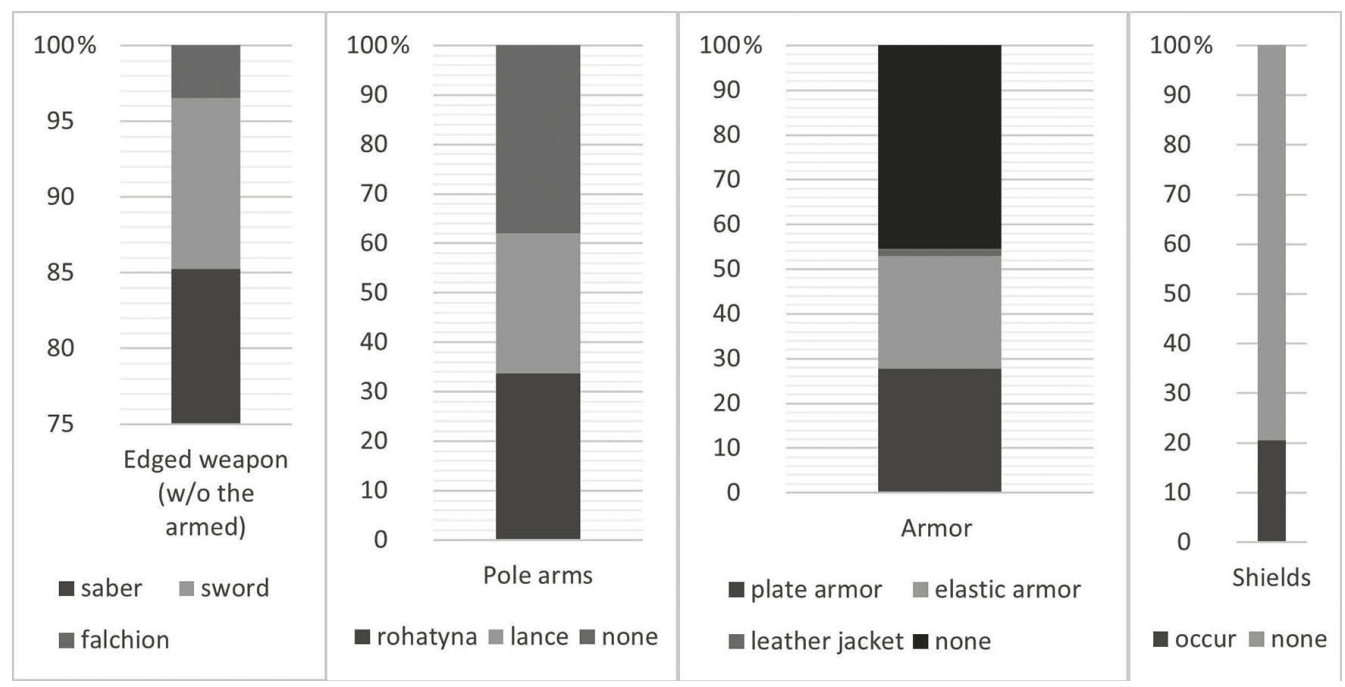

Fig. 5. Arms and armor of Lithuanian land service in register of 1524. Prepared by the authors on the basis of: [Popisy wojskowe... S. 1-19]

weapons they used, but the protective armament. This is best seen in the example of Boyar Juchno Czyżewicz, who had a 2-horse poczet. He himself possessed just an armor and a saber, and his servant had a shield and a spear with a big spearhead ${ }^{29}$. Pole weapons was not a decisive element of prestige which was guaranteed mainly by protective armament. Nearly $28 \%$ of soldiers owned heavy armors, and $24 \%$ - mail armor ${ }^{30}$. A marginal role was played by kabats (leather jackets, circa $2 \%)^{31}$. The rest of the soldiers, or as many as $46 \%$, did not have any form of body protection. Merely every fifth soldier possessed a shield (Fig. 5).

Probably the soldiers recorded in separate registers served in three different choragiews (rotas), in accordance with the rules regulating land service ${ }^{32}$. Thanks to this, we can examine the armament of particular units (Fig. 4). Details vary, but a major rule is evident. All the units have an extremely mixed composition, and their general characteristic can be seen only in their proportions. The Miedniki choragiew had the highest number of hussars, and the Rudomin chorąiew was characterized by the most numerous group of the heavy armed mounted soldiers (in the latter also the most numerous were

29 Popisy wojkkowe... S. 10.

30 Besides mail armors, this term could also cover baydanas and behterets, or even scale-armors (Archiwum Główne Akt Dawnych (Warsaw), Archiwum Skarbu Koronnego. Oddział 85. No. 19. L. 174v; Kř́ižek L., Čech Z. J. Encyklopedie zbraní a zbroje. Praha, 1999. S. 36, 186).

31 Leather jackets also featuredin the Crown cavalry (Archiwum Główne Akt Dawnych (Warsaw), Archiwum Skarbu Koronnego. Oddział 85. No. 19. L. 68, 78v, 86v).

32 The inspection was held five years before the 1st Lithuanian Statute was introduced; however, probably the general rules of mobilization were similar. In each unit, a chorąży was named who should command the unit. They were Ostryna Chorąży Miklasz Paszkowicz, Rudomino Chorąży Tomasz [Jakubowicz] and Miedniki Chorąży Jan [Zbrożek]. See: Łopatecki K. Organizacja, prawo i dyscyplina w polskim i litewskim pospolitym ruszeniu (do połowy XVII wieku). Białystok, 2013. S. 147-175; Urzędnicy Wielkiego Księstwa Litewskiego. Spisy. T. II: Województwo Trockie XIV-XVIII wiek / ed. A. Rachuba. Warszawa, 2009. S. 77; Urzędnicy Wielkiego Księstwa Litewskiego. Spisy. T. I: Województwo Wileńskie XIV-XVIII wiek / ed. A. Rachuba. Warszawa, 2004. S. 69-70. 


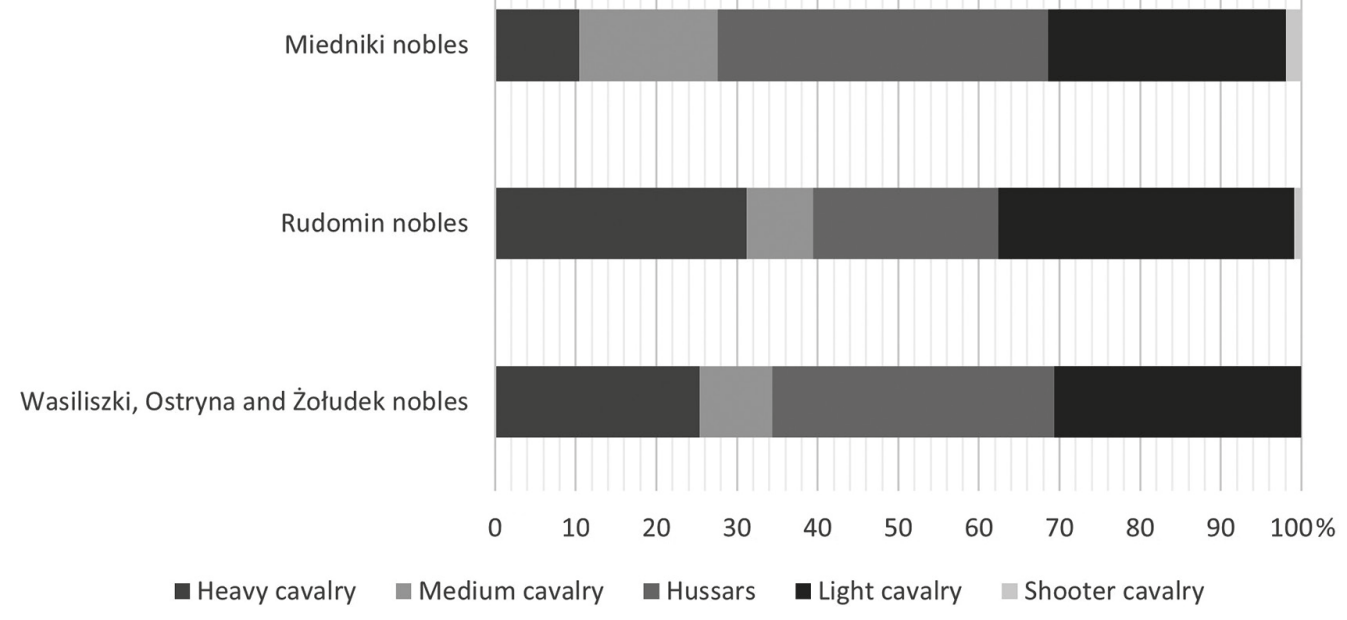

Fig. 6. Structure of the Lithuanian land service units in 1524. Prepared by the authors on the basis of: [Popisy wojskowe... S. 1-19]

the representatives of light cavalry). The most uniform division was noticeable in the Wasiliszki, Ostryna and Żołudek chorągiews, which probably resulted from their size. A big chorągiew had the highest statistical chance of a mixed composition. Moreover, practically no mounted shooters were present, at most merely 2 percent was noted in the Miedniki chorągiew. The division of the chorągiew was based on a territorial principle, and it was not the armament that affected the lack of specialized formations (see Fig. 6). SR is $36.97 \%$, so it is merely $63 \%$ of how standardized the cavalry units were for the expedition of 1531. The tactical superiority of the paid cavalry is unquestionable; disproportions are gigantic. Compared to the Crown units, where the proportions were also far from perfect, the situation in the mobilized units (pospolite ruszenie) was disastrous (Figs 3, 6). Certainly, the precise inspection register and the personal assessment of the combat units allowed the commander-in-chief to generally evaluate the combat potential of the units and to adapt them to tactical needs. The differences, however, were not fundamental and required very good insight on the part of the commanders.

Certainly, we are far from a conclusion that the Crown Mass Mobilization had the same armament structure as that of Lithuanian. The differences were surely important; probably in Poland lances and not spears with big spearheads dominated; probably the sword and not the sabre played a more important role. However, we want to focus attention on the fundamental element, which was the mixed composition of a choragiew (Fig. 5). No sources indicate that a different phenomenon occurred in the Crown units. Therefore, a much more real representation of the units than the one depicted in the Battle of Orsha painting, can be seen in a wing of the Triptych with the Legend of St. Hedwig of Silesia (Fig. 7). Despite the fact that the work was made circa.1440, it is positively more actual (of course, ignoring the elements of armament completely improbable in the battlefield, such as tournament helmets of frog mouth helm type worn by heavily armed lancers) as regards the combat concept of paid troops serving even in the 1530s. The work shows a very diversified chorągiew (rota), including lancers, demi-lancers, as well as light cavalry or fencers (Fig. 7). 


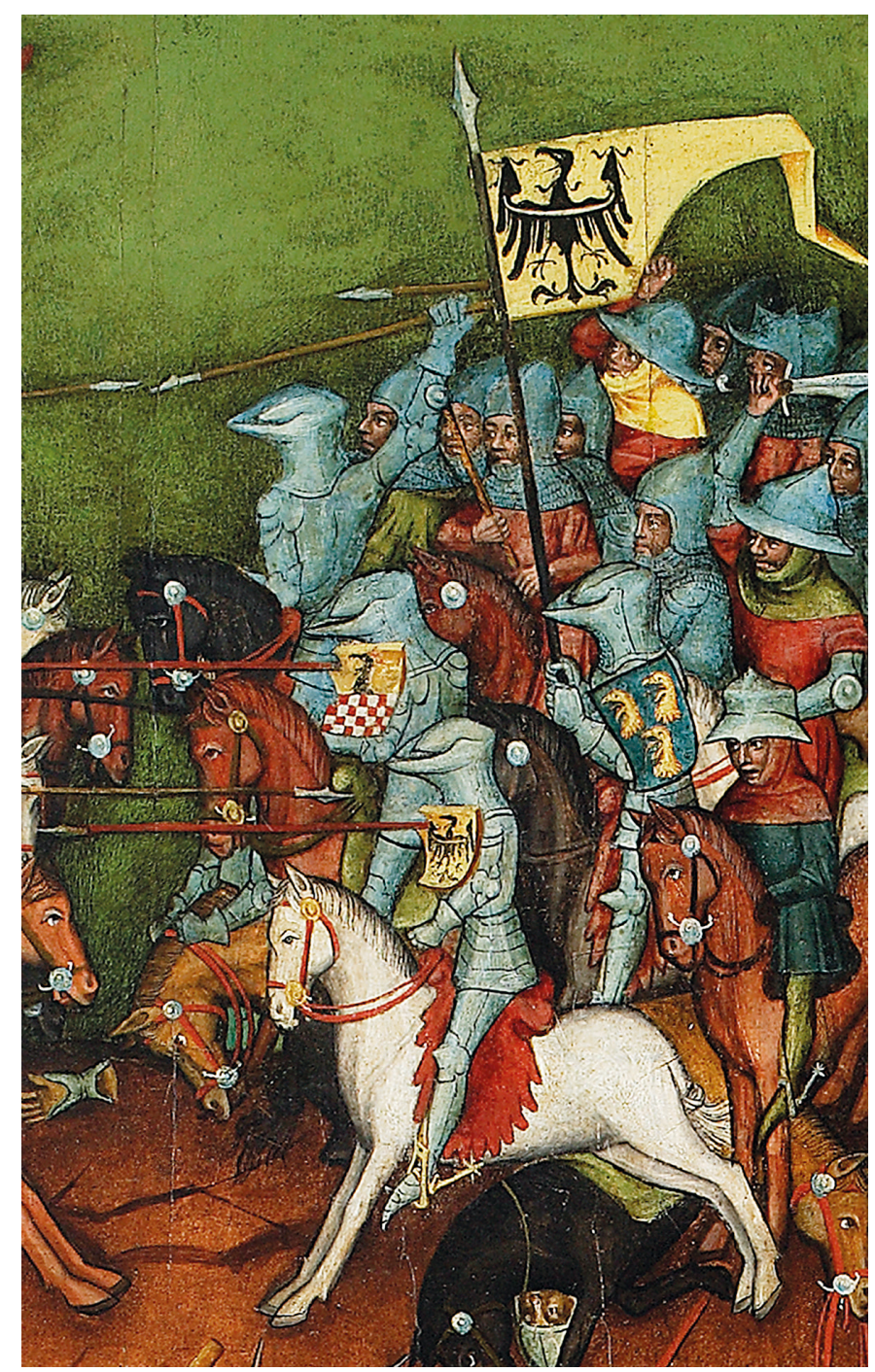

Fig. 7. Mass Mobilization (pospolite ruszenie) shown on the left wing of the Triptych with the Legend of St. Hedwig of Silesia [The National Museum in Warsaw, inv. No. Śr. 28 MNW. URL: https://commons.wikimedia.org/wiki/File:Anonymous_-_ Legend_of_Saint_Hedwig_-_Google_Art_Project.jpg]

Another factor, which long made it impossible to internally standardize the units in the Crown was the law. The regulations and institutions connected therewith, guaranteed abiding by the norms, generally financial, and were a perfect mechanism for forming homogeneous units at the time. Recruitment letters (listy przepowiednie) were a fine means of creating extensive rules of recruitment of soldiers ${ }^{33}$. Moreover, there was an opportu-

33 That is what Stephen Bathory did in the years 1576-77 (List przypowiedni na nadworną choragiew husarską z 1577 r. // Wypisy źródłowe do historii polskiej sztuki wojennej: w 13 t. T. 5 / eds Z. Spieralski, J. Wimmer, T. Nowak. Warszawa, 1961. S.41-43). 
nity during the inspection of the unit to verify preparation of an inspection register and payment ${ }^{34}$. The problem is that the military authorities failed to take up this opportunity. Certain rules were initially introduced in different normative acts.

The fist document concerning in particular the rules of recruitment was issued on April 4, 1525, as a set of regulations referring to recruitment of paid soldiers and specifying tax resolutions of the Piotrków Sejm ${ }^{35}$. At the request of Hetman Mikołaj Firlej, Chancellor Krzysztof Szydłowiecki and King Sigmund I issued Mandat Jego Królewskiej Miłości Pana naszego miłościwego ku popisowi wszytkich służebnych, jezdnych i pieszych ${ }^{36}$. It was the first legal historical document, whose original, authentic, edition was in the Polish language. It was no coincidence since the document was aimed at officers and had to be understandable by them ${ }^{37}$. It established the rules of military service in the Permanent Defense. This normative act included first and yet very general rules of armament. Everyone was ordered to possess horses and armors (point 3); the obligation of personal military service was introduced (point 4). An important obligation of the soldiers was to have at least one hand cannon in the 3-6-men poczet (point 6). The chorąży had to possess a plate armor (point 8). It is the first known case when the cavalry arms began to be regulated through the law.

Subsequent, considerably more important, actions were taken at the General Sejm debating at the turn of the 1528 in Piotrków. The debates were marked by the defeat at Mohács and the death of Louis of Hungary, as well as the expansion of the Ottoman Empire $^{38}$. As early as in 1527, it was decided that the king and the hetman would appoint in each province commanders of units selecting among noblemen in possession of property, who would then recruit 200-men chorągiews of cavalry ${ }^{39}$. The Sejm introduced a steady pay of 6 zlotys for a quarter, regardless of the armament, and a higher pay of 10 zlotys was assigned per main sub-unit (poczet) commanded by captain (rotmistrz) ${ }^{40}$. Thus the previous rules were changed, in light of which lancers, as graves armaturae, received a much higher pay. They earned 10 zlotys of a quarter pay, whereas the others -6 zlotys ${ }^{41}$. This phenomenon was one of the main factors of coexistence of heavy cavalry in all existent rotas. This action was justified since the lancers as the best armored stood in the first

34 Łopatecki K. "Disciplina militaris" w wojskach Rzeczypospolitej (do połowy XVII wieku). Białystok, 2012. S. 75-96.

35 Litterae universales de contributionum, Piotrków 17 II 1525 // Volumina constitutionum: in 4 vols. T. I, no. 1 / eds S. Grodziski, I. Dwornicka, W. Uruszczak. Warszawa, 1996. S. 428-431, pkt. 27-28.

36 Corpus Iuris Polonici. Volumina constitutionum. T. III / ed. O. Balzer. Kraków, 1906. S. 135-138; Łopatecki $K$. Artykuły rotmistrzowskie. Z badań nad kształtowaniem się wojsk zaciężnych w Koronie i Wielkim Księstwie Litewskim // Organizacja armii w nowożytnej Europie: struktura - urzędy — prawo — finanse. Zabrze, 2011. S. 65-66.

37 It is worth pointing out the rotmistrzes' letter of July 27, 1499, addressed to John Albert, which was written in Polish (Listy i akta Piotra Myszkowskiego, generalnego starosty ziem ruskich króla Jana Olbrachta / ed. A. Lewicki. Kraków, 1898. S. 37-38).

38 Wyczański A. Z dziejów reform skarbowo-wojskowych za Zygmunta I i próby relucji pospolitego ruszenia // Przegląd Historyczny. 1952. T. 43, no. 2. S. 287-304.

39 Acta Tomiciana, Epistolarum, legationum, responsorium, actionum et rerum gestarum Serenissimi Principis Sigismundi Primi regis Poloniae Magni Ducis Lithuaniae per Stanislaum Górski canonicum Cracoviensem et Plocensem collectarum. T. IX / eds A. T. Działyński, L. Koening. Poznań, 1876. S.71-72.

${ }^{40}$ Constitutio et ordinatio facta de suscipiendis militibus mercenariis ad praesidia terrarum Russiae // Volumina constitutionum. T. 1, nr.2 / eds W.Uruszczak, S. Grodziski, I. Dwornicka. Warszawa, 2000. P. 33-34.

${ }^{41}$ Plewczyński M. Żołnierz... S. 28-31, 38-39. 
line, due to which the losses from defensive weapons were reduced. However, in the era of transformations connected with the gunpowder revolution and increased maneuverability of the troops, it was a tactically erroneous conviction. The necessity to have circa $20 \%$ of shooters with firearms specified in the act of 152 should be treated likewise. This resulted in the combined composition of the units.

After 1527 the heavy cavalry did not disappear, which is clearly demonstrated in Fig. 3. It was a consequence of the normative act issued a year later by the new Grand Crown Hetman, Jan Tarnowski, entitled Pouczenie hetmana podskarbiemu koronnemu dane dla ogtaszania go rotmistrzom przy zaciagu wojska ${ }^{42}$. Similarly to the Mandat of 1525, the instruction was handed over to rotmistrzes at the moment of giving them recruitment letters and the money necessary to recruit a unit. It was an instruction of conduct addressed to the rotmistrzes and concerning the rules of recruitment, which had to be verified later during an inspection.

It included a general formula that the soldiers should possess appropriate armament and horses (point 1). Of key importance was point 2, which ordered rotmistrzes to have $20 \%$ lancers in their rotas. The hetman's justification was that in that case the unit was braver and hard-bitten in the combat with the enemy; he pointed out that this was necessary in the current circumstances (triumphs of the Ottoman troops). At the same time, he demanded that one shooter with a long hand cannon for every four horses be introduced into light cavalry. The scrutiny of the compositions of rotas in 1531 confirms that the rules were almost entirely implemented (Fig. 4).

The "rotmistrz articles" could and did form the structure of the units. Unfortunately, the subsequent normative acts of this type known to us dates only to the turn of the 1560s. They consisted of six articles addressed to cavalry units ${ }^{43}$. Of key importance was Article 1 , which ordered the towarzyszes to possess plate armors and not mail armor under the threat of rejection during the inspection (popis). Perhaps this should explain the transformation of hussars into heavy cavalry. Moreover, it was important that the riders on lancer horses should have plate armors, and mounted crossbowmen - should have mail armors. What is characteristic is the prescript to have swords instead of sabers, which is undoubtedly connected with the process of rearming those troops with estocs ${ }^{44}$.

There are also other, more extensive rotmistrz articles, which were given to at least some rotmistrzes in 1561 . The documents generally repeated the rules described above; however, they were clearly addressed to hussar units, which is evident in one additional article (2), which ordered all the soldiers in a unit to possess armors as well as lances and shields. Rejection of shields was accepted but pole arms were to be preserved. If the soldiers failed to have an armor, a mail armor was acceptable, but only in a full set: a shield

${ }^{42}$ Polskie ustawy i artykuły wojskowe od XV do XVIII wieku / ed. by S. Kutrzeba. Kraków. S. 38-39. In a new edition see: Spieralski Z. Instrukcje i artykuły hetmańskie Jana Tarnowskiego // Studia i Materiały do Historii Wojskowości. 1991. T.34. S. 275-277.

${ }^{43}$ Biblioteka Kórnicka (Kórnik), no. 1375. L. 70-72 (Articuli ktore mayą bicz opowiedane przi rozdawaniu pieniedzi rothmistrzom ieznim y dawane na czedułach). See: Biblioteka Jagiellońska (Cracov). No.7156 III; Korzeniowski J. Zapiski z rękopisów Cesarskiej Biblioteki Publicznej w Petersburgu i innych bibliotek petersburskich. Kraków, 1910. S. 60; Spieralski Z. Instrukcje... S.282-283; Jasnowski J. Materiały do działalności wojskowej Floriana Zebrzydowskiego // Przegląd Historyczno-Wojskowy. 1937. T.9, nr. 2. S. 272; Działyński Ł. Diariusz // Sprawy wojenne Stefana Batorego. Diariusze relacje, listy i akta z lat 15761586. Kraków, 1887. S. 240, 255-256.

${ }^{44}$ It is confirmed by the Rotmistrz Aricles of 1572, which also prohibited the use of saber. However, if a soldier had this weapon, the rider was obliged to possess, see: Polskie ustawy... S. 149. 


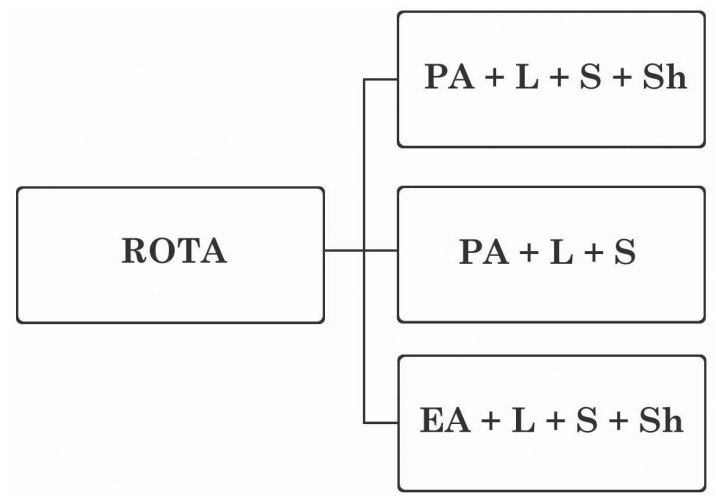

Fig. 8. Arms and armor of troops according to rotmistrz articles of 1561 . Key: PA - plate armor; MA - mail armor; L - lance; S - sword; Sh shield. Prepared by the authors on the basis of: [Rossiiskii Gosudarstvennyi Arkhiv Drevnikh Aktov. F. 12. No. 8. L. 8v]

and a lance ${ }^{45}$. This means that the rotas founded by virtue of that document were already uniformly armed formations of hussars having three similar types of arms and armor (see Fig. 8).

A third factor of diversity of arms in the units was their ununiformed structure. The Polish army was based on paid troops created by the social system. Having received a recruitment letter, a rotmistrz toured noble manor houses in the neighborhood and invited towarzyszes (fellow noblemen) to the unit which was being created. They took from their folwark (latifundium) a few trustworthy peasants, whom they armed and turned into their adjutants or pocztowys. The pocztowys served in the army but it was the towarzysz who received a pay for them, looked after them and ordered them ${ }^{46}$. This aspect impacted the arms and protective equipment. Usually, towarzysz was best armed. Consequently, even the combat order of a cavalry rota was modified, which is confirmed by the military articles published by Florian Zebrzydowski in 1561. In their light, the Polish cavalry arranged itself into four ranks. The first rank had to be consisted of towarzyszes and the best armed pocztowys. Then the well-armed horsemen were placed in the rear rank and on the sides. Simultaneously, the smallest horses and the worst protected soldiers were positioned in the middle of the rota. The second line was taken by servants obliged to assist their mas-

${ }^{45}$ Rossiiskii Gosudarstviennyi Arhiv Drevnih Aktov (Moskva). F. 12. No. 8. L. 8v. - The document is dated on the basis of two courtiers named in the document. One of them, Krzysztof Leśniowolski, died in 1561 (after May 8, 1561). - Ferenc M. Dwór Zygmunta Augusta. Organizacja i ludzie. Oświęcim, 2014. S. 219.

46 Bielski M. Sprawa rycerska // Archiwum domowe do dziejów i literatury krajowej. Warszawa, 1856. S.335; Górski K. Historya piechoty polskiej. Kraków, 1893. P. 6; Górski K. Historya jazdy polskiej. Kraków, 1894. S. 87-88; Koranyi K. Żołnierz najemny, a żołnierz zaciężny // Czasopismo Prawno-Historyczne. 1948. T. 1; Urwanowicz J. Wojskowe "sejmiki". Koła w wojsku Rzeczypospolitej XVI-XVIII wieku. Białystok, 1996. S. 32; Plewczyński M. Żołnierz... S. 23-37; Teodorczyk J. Polskie wojsko i sztuka wojenna pierwszej połowy XVII wieku // Studia i Materiały do Historii Wojskowości. 1978. T.XXI. S. 296. 
ters. Every pocztowy was also obliged to give his own horse to the towarzysz in the event of a dangerous situation ${ }^{47}$.

We think that it was also for this reason that Jan Tarnowski ordered to keep $20 \%$ of lancers in the unit. This would be the evidence for the formation of the unit to fight in five ranks. We have information from the years 1577-1580 that the hussars were arranged into five ranks, and the best-armed elite court units (curienses) - into merely three ${ }^{48}$. Such an arrangement had two advantages: the first rank's task was to break the enemy's array. Additionally, it was more resistant to fire. Illustration 3 from the mid- $15^{\text {th }}$ century perfectly represents this type of combat.

The combination of the first and the third factors, or a model based on the Mass Mobilization and the organization of the paid units in a social system, led to diversification in the units. The diversity was also supported by fiscal and legal regulations until 1527. Only after that year, normative acts, especially through the so-called rotmistrz articles, began to affect the process of unit standardization. In the first period, instead of standardization, they promoted unit diversification. Interestingly, the commanders-in-chief (hetmans), often outstanding strategists and commanders, did not perceive the need for creating uniformed cavalry units. Only from 1561 onwards the acts introduced rules of standardized armament (Fig. 8).

Clearly, neither the rulers nor the hetmans developed a concept leading to the standardization of a unit. On the contrary, they were against it. An example is here the Grand Crown Hetman Jan Tarnowski. In his military treatise, he emphasizes the need for possessing two types of cavalry: heavy and light (gravioris and levioris amaturae). He justified it saying that "ones without the others are not so useful, as they are one double formation" ${ }^{\prime \prime}$. Unfortunately, he did not mean a uniformly armed units but the combined composition of the rotas, which he had promoted intensively since the beginning of his office, and which we have already underscored in his instruction of 1528 .

The three aforementioned elements show that at least by the end of the 1550s, the diversity of units had to be high, very similar to that of 1531 (Fig. 3). Thus, we decided to examine the practice of arming cavalry units. For this purpose, we analyzed over 9,000 soldiers serving in the period of two considerable military campaigns (Figs 9, 10). One of the them was a summer campaign of 1538, when Jan Tarnowski attacked Moldavian Khotyn. Even though the siege was stopped, the hetman managed to sign a peace treaty with the Moldavian duke, favorable for Poland, and soon after his dethronement - to diplomatically defend the conditions of the agreement. There are data from that period referring to 7,066 soldiers of the paid cavalry ${ }^{50}$. The other important campaign was the so-called Pozwole expedition (1557). Actually, no sources directly connected with King Sigmund August's expedition to Livonia are known to us, but fiscal-military registers noting the presence of 2,213 cavalry soldiers to protect the state frontier at the south-eastern K. 3 .

${ }^{47}$ Rossiiskaia Nacional'naia Biblioteka (Sankt-Petersburg). Otdel rukopisei. F. 971. Avt. 321/1. No. 1.

48 Zborowski J. Dyaryusz zdobycia zamków // Sprawy wojenne Stefana Batorego. Diariusze relacje, listy i akta z lat 1576-1586. Kraków, 1887. S. 197; Działyński Ł. Diariusz... P.227; Kotarski H. Wojsko polsko-litewskie podczas wojny inflanckiej 1576-1582. Cz. 3 // Studia i Materiały do Historii Wojskowości. 1971. T.17. S. 116-117.

49 Tarnowski J. Consilium rationis bellicae. Warszawa, 1987. S. 45.

50 Bołdyrew A. Przemarsz armii koronnej pod Chocim podczas kampanii letniej 1538 roku w świetle dokumentacji skarbowo-wojskowej // Acta Universitatis Lodziensis. Folia Historica. 2019. T. 104. S. 47-60. 
Uniformed

Szachmanczir

Bodzanowski Jakub

Two-element

Cikowski Stanisław

Ciepłowski Jan

Bankrentus Andrzej

Zaręba Wacław

Gołuchowski Stanisław

Ciołek Wawrzyniec

Flamski Stanisław

Daniłowicz Jerzy

Ligęza Zbożny

Pieniążek Stanisław

Pierzchnieński Stanisław

Harynek Jerzy

Maciejowski Bernard

Grabski Jan

Parzynczewski Zygmunt

Paniowski Melchior

Tarło Stanisław

Zaborowski Jan

Pełka Zygmunt

Three-element

Oporowski Erazm

Mielecki Sebastian

Herburt

Ozga Piotr

Sobiekurski Szczęsny

Zoratyński Jan

Dobrosołowski Stanisław

Czartkowski Jerzy

Seceniowski Mikołaj

Kołaczkowski Mikołaj

Potocki Jakub

Krąpski Marcin

Jazłowiecki Jerzy

Lanckoroński Hieronim

Starzechowski Wojciech

Włodek Wieńczysław

Myszkowski Stanisław

Grudzieński Stefan

Rokitnicki Walerian

Gołdacz Piotr

Mielecki Jan

Jazłowiecki Prokop

Small units

Chodorowski Marcin

Pretwicz Bernard

Sieniawski Mikołaj$$
\text { - }
$$

0

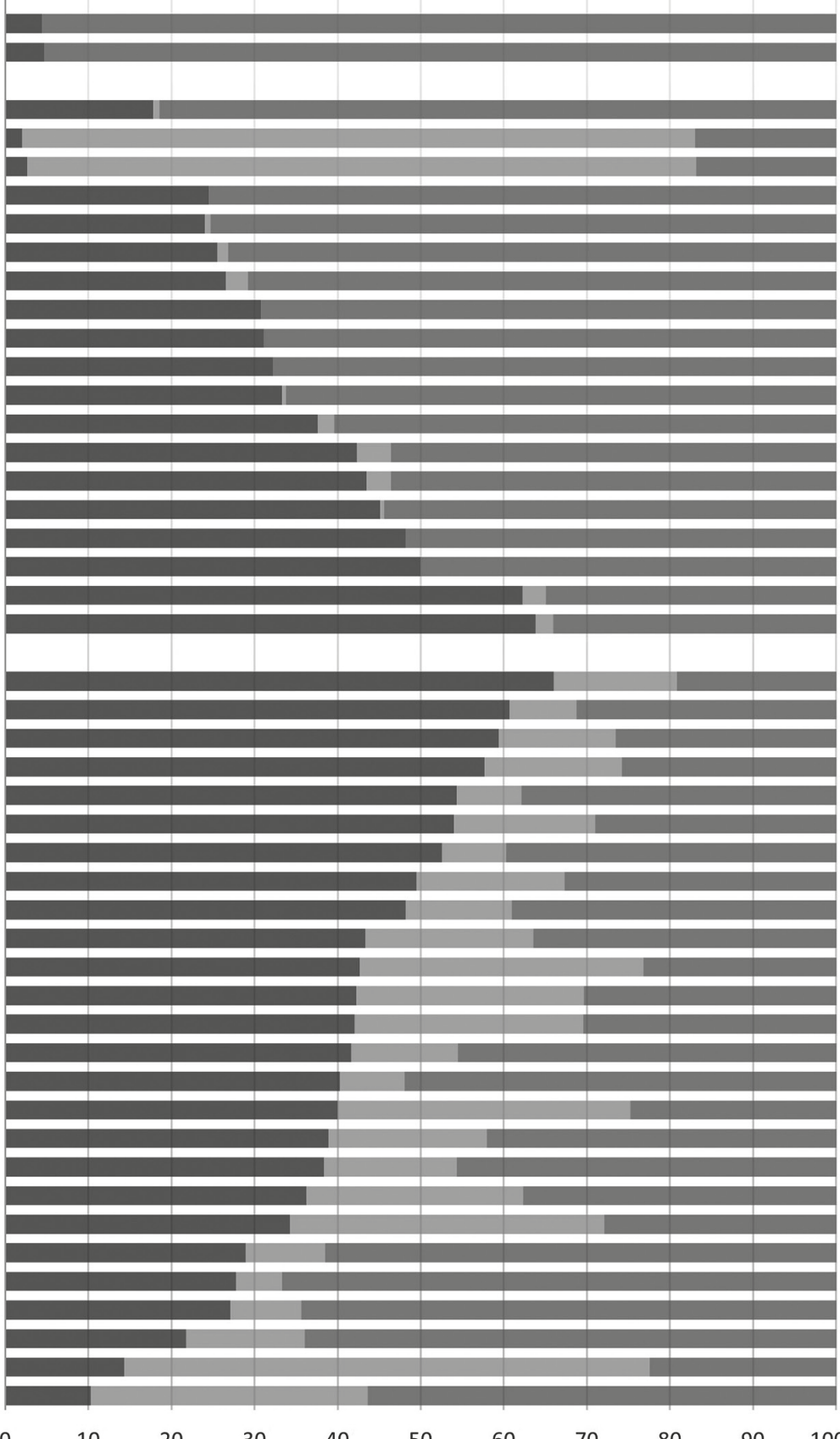

$$
\begin{array}{llllllllll}
10 & 20 & 30 & 40 & 50 & 60 & 70 & 80 & 90 & 100 \%
\end{array}
$$

- Lancers $\quad$ Winged Hussars $\quad$ Light cavalry

Fig. 9. Composition of cavalry rotas (with the names of the rotmistrzes) in the Moldavian campaign of 1538, by the category of cavalry soldiers. Prepared by the authors on the basis of: [Archiwum Główne Akt Dawnych (Warsaw), Archiwum Skarbu Koronnego. Oddział 85. No. 32. L. 3-137; No. 35. L. 2-160v] 


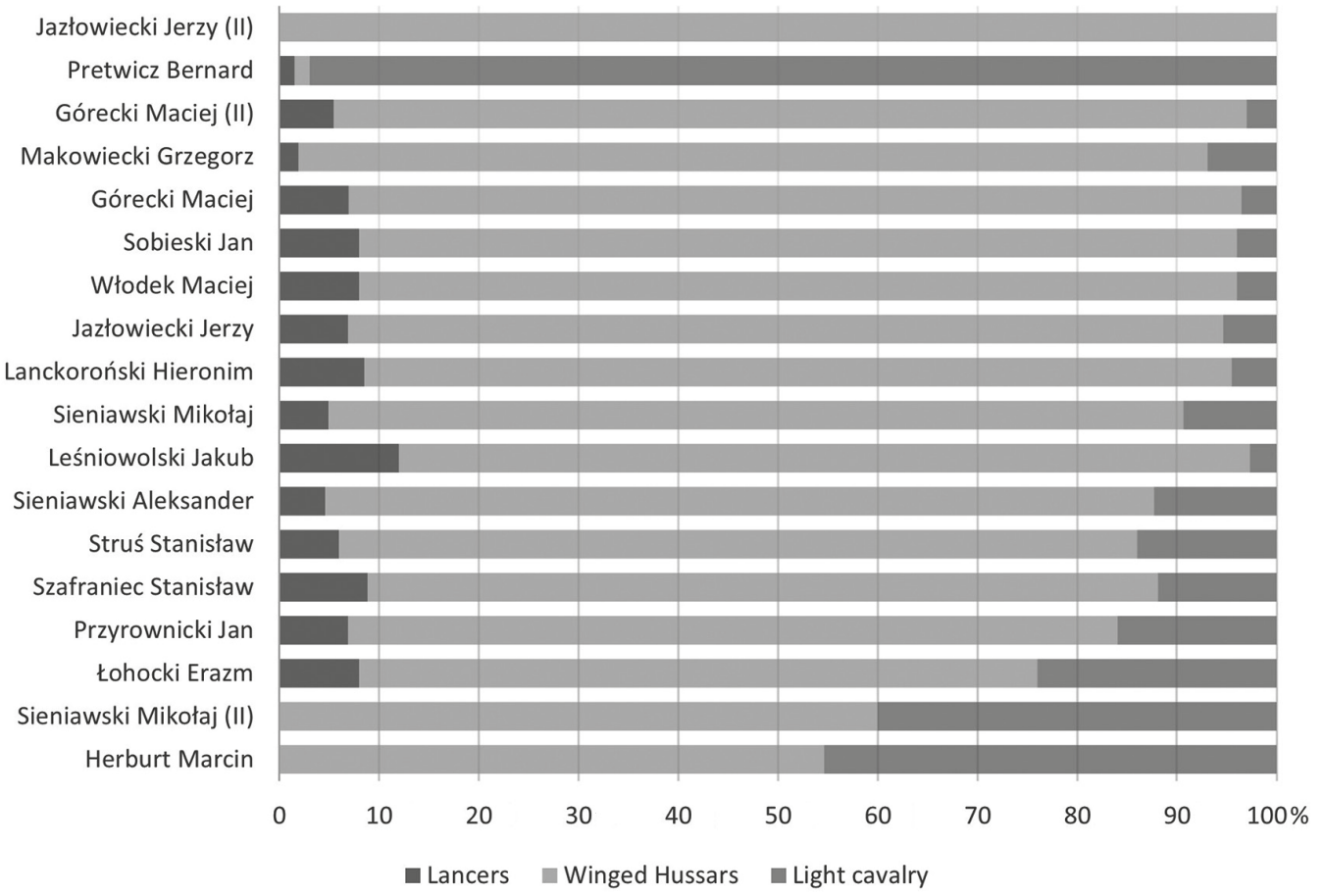

Fig. 10. Composition of cavalry rotas (with the names of the rotmistrzes) of Permanent Defense in 1557 by cavalry category. The units are arranged by standardization rate. Prepared by the authors on the basis of: [Archiwum Główne Akt Dawnych (Warsaw), Archiwum Skarbu Koronnego. Oddział 85. No. 61. L. 1-69]

borderlands of the Crown have survived. The source records allowed us to isolate three categories of cavalry (with certain internal diversity), which is heavy cavalry (lancers), medium cavalry (hussars) and light cavalry (mounted shooters with hand firearm and soldiers fighting in a Cossack or Tatar way).

In order not to distort the perception of the phenomenon, all units comprising fewer that 30 men are classified as „small units” (they were the rotas of Jerzy Daniłowicz, Stanisław Konarski, Jakub Secyniowski and an Aleksander). We grouped the results obtained in three categories: uniformed units, two-element units, and three-element units.

In 1538, the medium cavalry made up the lowest percentage: the hussars constituted $12.9 \%$ of the total army. The heavy lancer cavalry was very numerous since its share was $37.9 \%$. What is striking is the revival of cavalry of lancers, which seemingly proved its importance in combat actions against the Moldavian troops but was useless in clashes with the Tatars. This also suggests Jan Tarnowski's strong attachment to this type of military formation. The most numerous, on the other hand, was the light cavalry, which made up nearly a half of the army (49.2\%). It is important to underscore that it was the most internally diversified group in terms of the weapons and armor they used.

The example of 1538 is inspiring because it shows that quantitative analysis without qualitative analysis is deceptive. SR of $60.72 \%$ remains unchanged in relation to the year $1531(\mathrm{SR}=60.19)$. However, the analysis and comparison of figure 1 out of 5 demonstrates 
an entirely different internal structure of the army in terms of quality. Three-element rotas began to decline (i. e. those consisting of lancers, hussars and light cavalry) and there appeared units where the fundamental component was only two types of cavalry (twoelement rotas). Also, the first uniform units emerged. In the separation of two- and oneelement units, we adopted a conventional limit of $5 \%$. If a particular type of cavalry is represented below this value, we recognize that we deal with a uniform or two-element unit.

The first uniform units appeared in the army: those of Jakub Bodzanowski and Tatar Szachmanczir. In Bodzanowski's case, however, it is an ostensible uniformity since the soldiers of light cavalry did not differ much from one another. It does not change the fact that the 85-men unit became clearly standardized. The situation with the 91-men (Polish) Tatar rota of Szachmanczir was much better as $95 \%$ of it was uniformly armed.

It should be pointed out that the model for the Crown uniform composition of a unit was the Tatar military. Both the enemy's troops as well as Tatar rotas formed on the territory of the Crown and the Grand Duchy of Lithuania were of clearly uniform character. This is confirmed by, for example, the inspection of the Tatar choragiew of Achmed Ulan carried out for the needs of the Lithuanian army in 1534. Due to the precisely described weaponry we know that merely one soldier (out of 87 on the list of the unit) did not have a sahajdak (a bow in the case and a quiver with arrows). As many as $95.5 \%$ had a full set of arms: a saber and a sahajdak. Differences occurred in protective arms; the richest poczets possessed mail armors $(27.6 \%)$. Almost $3 / 4$ of the riders had neither a mail armor or any other kind of armor; nobody had a shield ${ }^{51}$. For their contemporaries, both units, of Ulan and Szachmanczir, were a phenomenon which could be imitated.

The model could also be observed thanks to foreign recruitments of uniform cavalry units. Now, the information about the earliest uniformly armed unit has been found in fiscal registers by Tadeusz Grabarczyk. It was the foreign hussar ("racka") rota commanded by Ferenc Raceni and Wacław Kamienicki. That 105 -men rota was recruited in $1498^{52}$. All the soldiers had lances and shields (SR $=100 \%)$. Unfortunately, such units were rare, but this fact? encouraged Polish rotmistrzes to reform their own units.

The phenomenon of standardization of hussar units was apparent as early as 1531 (Fig. 1). In those days, the front guard of Mikołaj Sieniawski, which consisted of merely 30 riders, was of such nature. The fact of isolation of a uniformed formation for the needs of reconnaissance signalled a change in the mindset behind rota organization. One of the first hussar rotas resembling a uniformed one, was the unit of Hetman Jan Koła of Dalejów. We are discussing here the year 1535 when the standardization rate was already $80 \%$, and in 1537 - even $88.14 \%$. It was a small unit (59 men in 1537, and two years earlier 70 men) but prestigious since its commander was the field Crown hetman ${ }^{53}$.

In 1538, the example of Jan Koła was followed by two rotas: of Andrzej Bankretus and Jan Ciepłowski with $80 \%$ of hussars ${ }^{54}$. The adopted rate is conventional, of course, but it illustrates our thesis well. It is worth noting that a similar situation also concerned

${ }^{51}$ Popisy wojskowe... S. 54-55.

52 Grabarczyk T. Po racku... S. 119.

${ }^{53}$ Kowalska H. Kola (Koło) Jan z Dalejowa h. Junosza (zm. 1543) // Polski Słownik Biograficzny. T. XIII. Wrocław, 1967. S. 285-286. - Warto zwrócić uwagę, że już jego ojciec - Piotr, w 1506 r. dowodził 180-osobowym oddziałem jazdy określanym jako husaria, cf. Gładysz A. The Polish-Moldavian conflict (1506) // War in History. The History of Polish and General Military Science. Lublin, 2017. P. 89.

54 Archiwum Główne Akt Dawnych (Warsaw), Archiwum Skarbu Koronnego. Oddział 85. No. 32. L. $133 \mathrm{v}-137$. 
two more chorągiews of light cavalry: of Jerzy Daniłowicz and Stanisław Konarsky (joint command) and of Stanisław Cikowski (respectively 88.9 and $81.5 \%)^{55}$.

Thus, we can state that in total, in 6 units out of 47 inspected, the phenomenon of standardization of armament occurred, and two of them were already entirely uniformed. In an absolute scale it referred to merely 669 soldiers of 7,066 listed in inspection protocols (circa 9.5\%). It is impossible, however, to show any key principle according to which soldiers with a particular set of arms were recruited. Full arbitrariness, even randomness, seems to confirm our suppositions that the paid army was mobilized on the basis of particular rotmistrzes' decisions. Even in the case of relatively uniformed units, the unification was clearly a question of fancy or of possibility of particular rotmistrzes, and not an effect of top-down planning.

In 1538 yet another phenomenon emerged, maybe of key importance for the subject under scrutiny. It is the transition from three-element units into two-element units. If in 1531 all the rotas were mixed and consisted of lancers, hussars and light cavalry (Fig. 3), seven years later we observe the first stage of the standardization of the units. It involved the existence of only two types of soldiers in a unit. This is seen in even 19 rotas (40.4\%). It is worth adding that two units are uniformed (2.3\%), and the remaining $26(55.3 \%)$ are still of the previous three-element nature (Fig. 6).

The third period which we examined is the year 1557 . Then 15 rotas were inspected in the first quarter and three subsequent ones in the second quarter (turn of 1558). After 20 years the paid cavalry underwent enormous transformations, which clearly indicate attempts at setting the composition of units in order. Firstly, SR is as high as $82.93 \%$, so the increase noted from the previous survey was by $36.6 \%$. Secondly, traditional three-element rotas played a marginal role. Among them were the units of Stanisław Struś, Stanisław Szafraniec, Jan Przyrownicki and Erazm Łohocki, but even there the standardization rate was $80,79,77$ and $68 \%$. The first three actually had an up-to-date structure. Thirdly, there were still two-element rotas, but they could be observed only in Marcin Herburt's unit, in Aleksander Sieniawski's unit and Mikołaj Sieniawski's unit (II). Furthermore, there occurred a spectacular standardization of units. In those days four fully homogeneous rotas were inspected: those of Jerzy Jazłowiecki (II): $100 \%$; Bernard Pretwicz: 96.9\%; Maciej Górecki (II): 91.5\%; and Grzegorz Makowiecki: $91.1 \%$. SR in the range $85-90 \%$ could be found in as many as seven units: of Maciej Górnicki: 89\%; Maciej Włodek: $88 \%$; Jan Sobieski: $88 \%$; Jerzy Jazłowiecki: $87.7 \%$; Hieronim Lanckoroński: $87 \%$; Mikołaj Sieniawski: 85.7\%; and Jakub Leśniowolski: $85.3 \%$. Within the range $80-85 \%$ there were next two units: of Aleksander Sieniawski (83.1\%) and of Stanisław Struś (80\%). Thus, in half of cases (50\% of units) partial standardization was achieved, and in over $22 \%$ - the process was completed. Actually, except for the unit of Erazm Łohocki (8\% lancers, $68 \%$ hussars and $24 \%$ of light cavalry), all the units were transformed or clearly sought uniformity. Hussars achieved a dominating role, except the unit of Bernard Pretwicz, which had the qualities of Cossack cavalry ${ }^{56}$.

Undoubtedly, it was between 1538 and 1557 that the quantitative changed occurred. To illustrate chronologically the progressing phenomenon, we scrutinized three representative chorągiews (rotas) of cavalry and analyzed their inspection data for 20 years (Fig. 11).

55 Archiwum Główne Akt Dawnych (Warsaw), Archiwum Skarbu Koronnego. Oddział 85. No. 32. L. 3-14v, 128-129; No. 35. L. 39v - 42, 146-147.

56 Ibid. No. 61. L. 18-21v. 


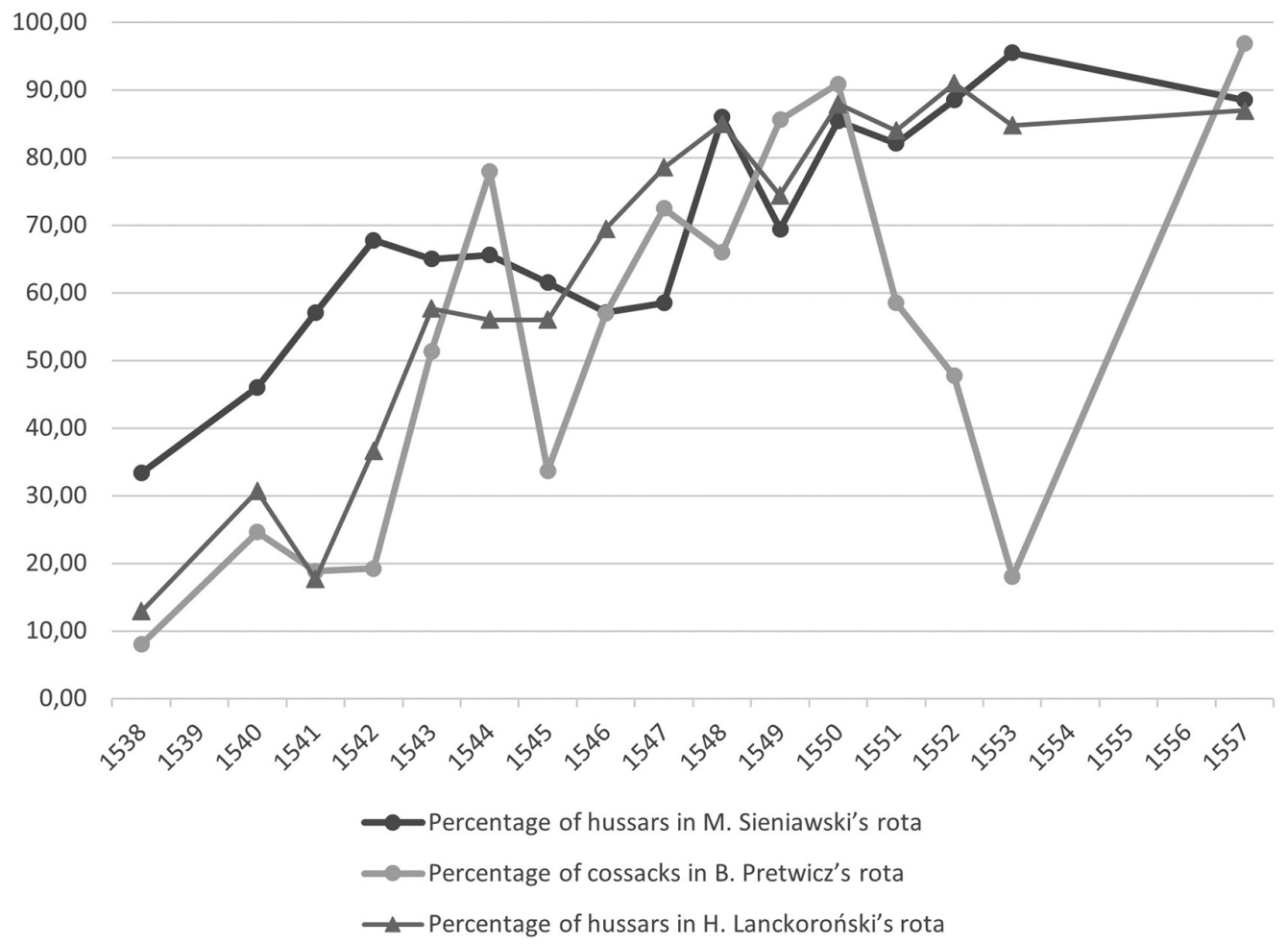

Fig. 11. Process of uniformity of the units (annually) as in the rotas of Bernard Pretwicz, Mikołaj Sieniawski and Hieronim Lanckoroński. Prepared by the authors on the basis of: [Archiwum Główne Akt Dawnych (Warsaw), Archiwum Skarbu Koronnego. Oddział 85. No. 32, 35, 36, 39-42, 44, 48-61]

We took into consideration the rotas of Mikołaj Sieniawski (holding the office of field hetman in the years 1539-1560), Bernard Pretwicz (starost of Bar and then Trembowla) and Hieronim Lanckoroński (starost of Skała Podolska). In 1557 each of them commanded a uniformed unit; Sieniawski and Lanckoroński based the composition of ther rota on hussars, whereas Pretwicz - on cossacks. In total, 8.271 soldiers went through the rotas of those three commanders (Sieniawski: 3.346, Pretwicz: 2.910, Lanckoroński: 2.015).

In Fig. 5 we observe the percentage of the type of cavalry dominating in 1557. In Pretwicz they are Cossacks, in the remaining two - hussars. Unfortunately, accounts for the years 1554-1556 have not not survived and are unknown. Despite this gap, the growing tendency is constant and clear (except for B. Pretwicz's rota, which is yet to be discussed below). There is no leap of SR, which means that the process was not stimulated by normative acts or decisions taken by the hetman or the king. In spite of different points of departure, the symbolic moment of rearmament of soldiers (SR $=80 \%$ or higher) in all three rotas falls on the common period. In the case of Sieniawski's and Lanckoroński 's rotas it is $1548 / 1550$, and in the case of Pretwicz's rota - 1549/1550. It is a phenomenon characteristic of most of the remaining rotas in the analogous period; however, the transformations usually referred to the hussars ${ }^{57}$. From 1550 onwards, the percentage of

57 For example, in 1548, in Maciej Włodek's unit hussars made up 84\% of the personnel (see: Archiwum Główne Akt Dawnych (Warsaw), Archiwum Skarbu Koronnego. Oddział 85. No. 52. L. 3-6v). 
hussars in the rotas of Sieniawski and Lubomirski does not fall below $80 \%$, and reaches even $90 \%$.

As regards Bernard Pretwicz, the situation is more complicated and requires explanation. Initially, the most numerous groups were hussars (in 1539 they made up $86.7 \%$ ), but from the moment of assuming the office of a starost of borderland Bar in 1542, the optics of the commander changed. He needed soldiers capable of carrying out reconnaissance in the distant areas; he also conducted plundering expeditions to Ottoman and Tatar lands. Therefore, from the spring of 1542 onward we can observe a tendency of reducing the number of hussars in favor of Cossacks ${ }^{58}$. For the first time the threshold of $80 \%$ was crossed in $1544^{59}$, and then in 1549 and $1550^{60}$. In the summer 1552, on the demand of the Ottoman Empire, Pretwicz was ousted of Bar (and moved to Trembowla, distant from the frontier $)^{61}$. Then he chose hussars again, abandoning the value of huge mobility in favor of increasing the combat value ${ }^{62}$. The figure perfectly demonstrates the political turmoil around the rotmistrz and testifies to the conscious personal policy of the commander. SR in his troops tends to fluctuate the most. This means that he was perfectly able to rearm his unit within 2 years, giving it a completely different form. New strategic needs (reconnaissance) resulted in the situation where in 1557, during patrol service at the borderline, Cossacks again dominated in his troops $(96.9 \%)^{63}$. Simultaneously, in the other two rotmistrzes we can see a slowly rising line, which suggests conducting a consistent, yet not revolutionary (as in Pretwicz's rota) policy.

The detailed analysis of the rotas' compositions in the years 1538-1557 indicates that in 1538 all the units consisted of three elements (respectively: heavy cavalry/ medium cavalry/light cavalry: M.Sieniawski: 10.26/33.33/56.41\%; H.Lanckoroński: 41.63/12.88/45.49\%; B. Pretwicz: 10/59/31\%). Each of the units represented another specificity: in Sieniawski's it was light cavalry, in Lanckoroński's - heavy cavalry, and in Pretwicz's rota hussars dominated. The transition to the two-element structure occurred at earliest in Pretwicz's unit. It took place in 1540, and then continued from 1543 onwards. In Lancoroński 's rota it was in 1547, and in Sieniawski's rota - in 1548. A one-element unit, or the one where there were not more than $5 \%$ of other types of cavalry, emerged the earliest under Sieniawski, in the fall-winter recruitment 1552/1553. In 1553, he still had an excellent rate, which slightly fell in the summer $1557^{64}$. Pretwicz achieved this rate only in 1557, and Lanckoroński never completed the transformation, yet he was close to it ${ }^{65}$.

58 Archiwum Głowne Akt Dawnych (Warsaw), Archiwum Skarbu Koronnego. Oddział 85. No. 41. L. 20-22.

59 Ibid. No. 48. L. 27-31.

60 Ibid. No. 54. L. 18-27; No. 50. L. 18-27.

61 Tomczak A. Pretwicz (Pretfic) Bernard h. Wczele // Polski Słownik Biograficzny. T.XXVIII. Wrocław, 1984-1985. S. 433-435; Maleczyński K. Urzędnicy grodzcy trembowelscy // Ziemia Czerwieńska. 1936. T. 2, nr. 2. S. 307; Dziubiński A. Polsko-litewskie napady na tureckie pogranicze czarnomorskie w epoce dwu ostatnich Jagiellonów // Kwartalnik Historyczny. 1996. T. 103. S. 53-85.

${ }^{62}$ In fall 1553 it reaches 90.59 hussars (Archiwum Główne Akt Dawnych (Warsaw), Archiwum Skarbu Koronnego. Oddział 85. No. 57. L.20-27; No.60. L.36v - 39).

63 Ibid. No. 61. L. 18-21v.

64 The rates were as follows: $1552-2,01 / 96,48 / 1,51 \% ; 1553-3,37 / 95,51 / 1,12 \% ; 1557-5,5 / 88,5 / 6 \%$ (Ibid. No. 57. L. 2-10; No. 60. L. 3-9v; No. 61. L.4-9v, 66-66v).

65 The rates were as follows: $1550-2,2 / 87,91 / 9,89 \% ; 1551-4 / 84 / 12 \%$; spring $1552-7 / 92 / 1 \%$; summer 1552 - 10,05/88,94/1,01\%; autumn 1552 - 7/92/1\%; $1553-8,7 / 84,78 / 6,52 \%$; 1557 8,54/86,93/4,52\% (Ibid. No.55. L.43-47; No.56. L.41-45; No.57. L.32-35v; No.58. L.XXXI-XXXVIII; No.59. L. 15-18v, 32-36; No. 61. L. 40v-45). 
In the article we followed the process of internal standardization of cavalry units. At the beginning of the $16^{\text {th }}$ century, such rotas were very diverse in the Crown army (see Fig. 7). Simplifying their structure, we can say that as a rule all of them had three elements, i. e. they consisted of lancers, hussars and light cavalry mixed in different proportions. This phenomenon is shown in figure 1, which represents the personal composition of units in 1531. We connect this state of affairs with three factors. Firstly, the units of Permanent Defense referred in their structure to Mass Mobilization (see Figs 4-6). Secondly, provisions of law were not used to uniform weaponry and armor; on the contrary, at least until the 1530s they stimulated internal diversity. Thirdly, the Crown mercenaries were internally divided into towarzyszes and pocztowys, which encouraged diversification of the arms inside the unit.

In order to follow quantitative changes, we introduced SR, which shows the percentage of the dominating type of cavalry in the unit. We managed to establish that in the Lithuanian Mass Mobilization of 1524, SR was 36.9\% (Fig. 6). The units of Permanent Defense in 1531 made up $60.19 \%$ (Fig. 3) ${ }^{66}$. We can point out the tactical advantage of the paid cavalry over Mass Mobilization. However, it is difficult to recognize the result as impressive, and the standard armament of the nobility participating in Mass Mobilization was embarrassing: they used 24 different sets of armament/armature (Figs 4-6). SR did not change in 1538 and was $60.72 \%$ (Fig. 9). The key changes took place over the subsequent 20 years. In 1557, SR was already $82.93 \%$ (Fig. 10). The changes towards uniformity of units were not forced by state officials, rulers or hetmans. Moreover, Hetman Jan Tarnowski controlling the army in the years 1527-1559 (intermittently) was not a champion of internal standardization of units. It was not until 1561 that the rotmistrz articles indicated the need for standardized arming of towarzyszes, but even then there were three sets thereof (see Fig. 8) ${ }^{67}$. The ruler who fully made use of normative acts for rearming and standardizing cavalry units was Stefan Bathory, which was implemented in the years 1576-1577.

We believe that in the second and the third quarter of the $16^{\text {th }}$ century, the actors of transformations (agents of the dynamic changes in armament) were middle level commanders, especially rotmistrzes and starosts. Such people had real opportunities for acting and implemented a certain modernizing plan, and were also aware of the aim they wanted to achieve (Fig. 10). Paradoxically, the medieval tradition, according to which one unit contained different categories of troops, was helpful. Thanks to that, commanders observed on an ongoing basis not only cooperation of soldiers using different sets of arms, but also their usefulness in combat with a particular enemy. They also could compare their observations with those of the commanders of other units, which had a different armament structure. We believe that the models could be borrowed from the Tatar military, where SR reached $95 \%$, and also from mercenary troops recruited abroad (also armed uniformly).

66 The examination of three Mass Mobilization units of 1524 demonstrates that the greatest difference between them and the paid troops was the common lack of shooting arms.

67 This was not the initiative of Jan Tarnowski but that of Florian Zebrzydowski who commanded the recruitment of soldiers in 1561 dispatched to Livonia (Lesmaitis G. LDK samdomoji kariuomene XV a. pabaigoje - XVI a. antrojoje puseje. Vilnius, 2010. P. 83-86). 
The quality analysis of the personal composition shows that during the first stage of the process of standardization three-element units were replaced with two-element units. The process is clearly visible in 1538 (Fig. 9). Then comes a slow, long quantitative strengthening of the principal type of cavalry. Usually, it was hussars; very rarely Cossack cavalry (Fig. 10). Lancers and types of light cavalry other than Cossacks disappeared. The detailed analysis of the personal composition of three rotas in the years 1538-1557 demonstrated that the process was gradual but consistent. The vast majority of the units reached the breakthrough SR threshold (80\%) in the years 1548-1550. It is necessary to admit that it was achieved without institutional decisions, which is an impressive result and constitutes an example of bottom-up military reforms.

\section{References}

Bołdyrew A. The Bow in the Borderland in the $16^{\text {th }}$ Century. Fasciculi Archaeologiae Historicae, 2017, t. 30, S. 11-17.

Bołdyrew A. Piechota zaciężna w Polsce w pierwszej połowie XVI wieku. Warszawa, Wydawnictwo Neriton, 2011, 420 s.

Bołdyrew A. Przemarsz armii koronnej pod Chocim podczas kampanii letniej 1538 roku w świetle dokumentacji skarbowo-wojskowej. Acta Universitatis Lodziensis. Folia Historica, 2019, t. 104, S. 47-60.

Cichowski J., Szulczyński A. Husaria. Warszawa, Wydawnictwo Ministerstwa Obrony Narodowej, 1977, 244 s.

Dziubiński A. Polsko-litewskie napady na tureckie pogranicze czarnomorskie w epoce dwu ostatnich Jagiellonów. Kwartalnik Historyczny, 1996, t. 103, S. 53-85.

Ferenc M. Dwór Zygmunta Augusta. Organizacja i ludzie. Oświęcim, Wydawnictwo Napoleon V, 2014,398 s.

Filipczak-Kocur A. Skarbowość Rzeczypospolitej 1587-1648. Projekty, ustawy, realizacje. Warszawa, Wydawnictwo Sejmowe, 2006, 437 s.

Gładysz A. The Polish-Moldavian conflict (1506). War in History. The History of Polish and General Military Science. Lublin, Instytut Historii KUL, Pracownia Wojskowo-Historyczna, 2017, S. 85-102.

Głubisz B. Jazda kozacka w armii koronnej 1549-1696. Poznań, Wydawnictwo Poznańskie, 2016,364 s.

Górski K. Historya jazdy polskiej. Kraków, Księgarnia Spółka Wydawnicza Polska, 1894, 375 s.

Górski K. Historya piechoty polskiej. Kraków, Księgarnia Spółka Wydawnicza Polska, 1893, 282 s.

Grabarczyk T. Jazda zaciężna Królestwa Polskiego w XV wieku. Łódź, Blue Note, 2015, 308 s.

Grabarczyk T. Po racku, po husarsku, z przyprawą tatarską — początki przemian wojskowości polskiej u schyłku XV wieku. In tempore belli et pacis. Ludzie - Miejsca - Przedmioty. Warszawa, Wydawnictwo DiG, 2011, S. 117-128.

Grabarczyk T. Uzbrojenie w rocie konnej Aleksandra Sewera z 1498 roku. Archaeologia Historica, 2009, t. 34, nr. 1, S. 445-453.

Janicki M. A. Obraz Bitwa pod Orszą - geneza, datowanie, wzory graficzne, a obraz bitwy "na Kropiwnej” i inne przedstawienia batalistyczne w wileńskim pałacu Radziwiłłów. Bitwa pod Orszą. Warszawa, Wydawnictwo Neriton, 2015, S. 173-225.

Kałużny J. T. U boku króla. Chorągiew nadworna królów Polski u schyłku XV wieku. Acta Universitatis Lodziensis. Folia Historica, 2019, t. 103, S. 59-72.

Kolankowski L. Roty koronne na Rusi i Podolu 1492-1572 r. Ziemia Czerwieńska, 1935, t. 1, nr. 2, S. $141-174$.

Koranyi K. Żołnierz najemny, a żołnierz zaciężny. Czasopismo Prawno-Historyczne, 1948, t. 1, S. $105-108$.

Korzeniowski J. Zapiski z rękopisów Cesarskiej Biblioteki Publicznej w Petersburgu i innych bibliotek petersburskich, Kraków, Biblioteka Jagiellońska (Cracov), 1910, 548 s.

Kotarski H. Wojsko polsko-litewskie podczas wojny inflanckiej 1576-1582, part 1. Studia i Materiały do Historii Wojskowości, 1970, t. 16, nr. 2, S. 63-123.

Kotarski H. Wojsko polsko-litewskie podczas wojny inflanckiej 1576-1582, part 3. Studia i Materiały do Historii Wojskowości, 1971, t. 17, nr.2, S. 81-151. 
Kowalska H. Kola (Koło) Jan z Dalejowa h. Junosza (zm. 1543). Polski Słownik Biograficzny, t. XIII. Wrocław, Zakład Narodowy im. Ossolińskich, 1967, S. 285-286.

Křížek L., Čech Z. J. Encyklopedie zbraní a zbroje. Praha, Nakladatelstvi Libri, 1999, 328 s.

Lesmaitis G. LDK samdomoji kariuomenè XV a. pabaigoje - XVI a. antrojoje pusejje. Vilnius, Baltų lankų leidyba, 2010, $224 \mathrm{~s}$.

Łopatecki K. Artykuły rotmistrzowskie. Z badań nad kształtowaniem się wojsk zaciężnych w Koronie i Wielkim Księstwie Litewskim. Organizacja armii w nowożytnej Europie: struktura - urzędy prawo - finanse. Zabrze, Infort Ediotions, 2011, S.63-81.

Łopatecki K. "Disciplina militaris" w wojskach Rzeczypospolitej (do połowy XVII wieku). Białystok, Instytut Badań nad Dziedzictwem Kultowym Europy, 2012, 801 s.

Łopatecki K. Organizacja, prawo i dyscyplina w polskim i litewskim pospolitym ruszeniu (do połowy XVII wieku). Białystok, Instytut Badań nad Dziedzictwem Kultowym Europy, 2013, 660 s.

Maleczyński K. Urzędnicy grodzcy trembowelscy. Ziemia Czerwieńska, 1936, t. 2, nr. 2, S.302-317.

Niemczyk K. Wojskowa emanacja władzy królewskiej w osobie hetmana na przełomie XV i XVI w. Władza a społeczeństwo. Katowice, Wydawnictwo Uniwersytetu Śląskiego, 2016, S. 151-161.

Pałucki W. Drogi i bezdroża skarbowości polskiej XVI i pierwszej połowy XVII wieku. Wrocław, Zakład Narodowy im. Ossolińskich, 1974, 308 s.

Pałucki W. Reformy skarbowe sejmu egzekucyjnego 1562/1563 r. Studia historyczne. Ksiega Jubileuszowa $z$ okazji 70 rocznicy urodzin prof. dra Stanisława Arnolda. Warszawa, Książka i Wiedza, 1965, S. 301-313.

Plewczyński M. Napierśniki husarii obrony potocznej w połowie XVI w. Studia z Dziejów Wojskowości, 2017, t. VI, S. 161-178.

Plewczyński M. W stużbie polskiego króla. Z zagadnień struktury narodowościowej Armii Koronnej w latach 1500-1574. Siedlce, Wydawnictwo Uczelniane WSRP w Siedlcach, 1995, $322 \mathrm{~s}$.

Plewczyński M. Wojny i wojskowość polska w XVI wieku, t. I: Lata 1500-1548. Zabrze, Infort Editions, 2011, $460 \mathrm{~s}$.

Plewczyński M. Żołnierz jazdy obrony potocznej za czasów Zygmunta Augusta. Studia nad zawodem wojskowym w XVI w. Warszawa, Państwowe Wydawnictwo Naukowe, 1985, 316 s.

Spieralski Z. Instrukcje i artykuły hetmańskie Jana Tarnowskiego. Studia i Materiały do Historii Wojskowości, 1991, t. 34, S. 271-308.

Spieralski Z. Kampania obertyńska 1531 roku. Warszawa, 1962. 314 s.

Sucheni-Grabowska A. Walka o wymiar i przeznaczenie kwarty w końcu XVI w. i na początku XVII w. Przegląd Historyczny, 1963, t. 56, S. 24-44.

Teodorczyk J. Polskie wojsko i sztuka wojenna pierwszej połowy XVII wieku. Studia i Materiały do Historii Wojskowości, 1978, t. XXI, S.291-316.

Tomaszewski P. Husaria najlepsza jazda nowożytnej Europy. Saeculum Christianum, 2010, t. 17, nr. 1, S. 5-21.

Tomczak A. Pretwicz (Pretfic) Bernard h. Wczele. Polski Słownik Biograficzny, t. XXVIII. Wrocław, Zakład Narodowy im. Ossolińskich, 1984-1985, S. 433-435.

Urwanowicz J. Wojskowe "sejmiki". Koła w wojsku Rzeczypospolitej XVI-XVIII wieku. Białystok, Dział Wydawnictw Filii UW w Białymstoku, 1996, 272 s.

Wyczański A. Z dziejów reform skarbowo-wojskowych za Zygmunta I i próby relucji pospolitego ruszenia. Przegląd Historyczny, 1952, t. 43, nr. 2, S.287-304.

Статья поступила в редакцию 2 июня 2020 г. Рекомендована в печать 12 марта 2021 г.

Received: June 2, 2020

Accepted: March 12, 2021 